\title{
Evaluation of Photosynthetic and Yield Traits in Ten Potato Clones and Cultivars Under Farming Conditions in Poland
}
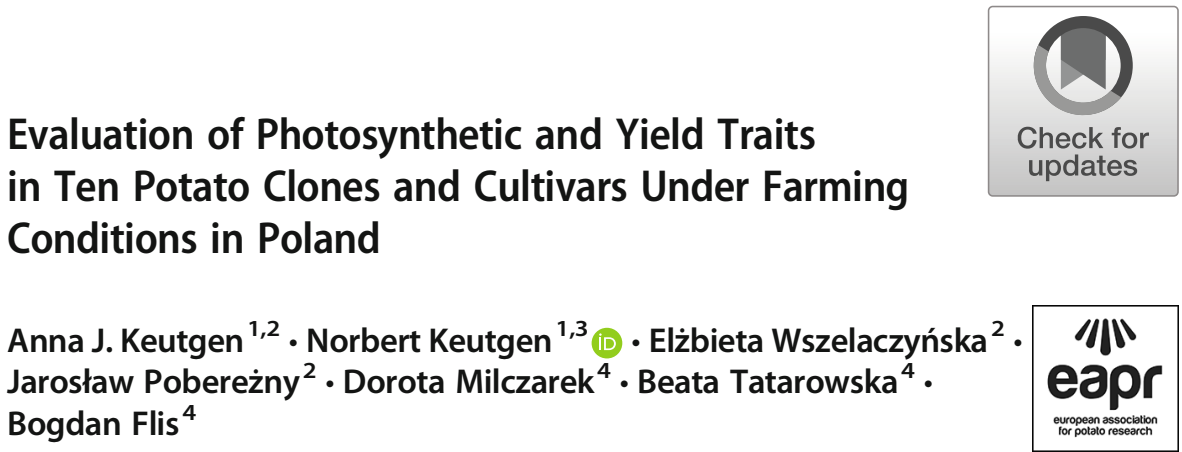

Received: 25 March 2018 / Accepted: 24 May 2019/

Published online: 2 July 2019

(C) The Author(s) 2019

\begin{abstract}
Photosynthetic properties and tuber yield were compared in seven tetraploid potato (Solanum tuberosum L.) clones ('13-VIII-10', '13-VIII-27', '13-VIII-45', '13-VIII-49', '13-VIII-50', '13-VIII-60', 'TG-97-403') and three cultivars ('Jelly', 'Satina', 'Tajfun') at four localities in Poland under either integrated (Młochów, Boguchwała) or organic (Radzików, Chwałowice) fertilisation conditions applying the 'OJIP' analysis of chlorophyll fluorescence kinetics. The yield-relevant parameters of leaf pigment content and chlorophyll fluorescence were used to rank the tested clones and cultivars applying multidimensional comparative analysis. The results indicate that the clones 13-VIII-10 and 13-VIII-45 cannot be recommended for cultivation, while cv. Taifun performed the best. The assessment of the efficiency of the light reactions of photosynthesis produced a different ranking, indicating that the efficiency is not related to yield, but characterises the balance between light harvesting and dark reactions of photosynthesis. In this respect, the light reactions of photosynthesis were least balanced in clone 13-VIII-49 and cv. Jelly while those of cv. Taifun and clone 13-VIII-60 were the best. The effect of the production system was of minor significance for tuber yield, but local factors dominated. Only in the case of chlorophyll (Chl) and carotenoid (Car) contents of leaves did an effect of the production system became evident, favouring integrated over organic cultivation. By contrast, most of the chlorophyll fluorescence parameters were controlled by soil nitrogen content, including maximum quantum yield for primary photochemistry $\left(\varphi_{\mathrm{P} 0}\right)$ and the absolute and total performance indices $\left(\mathrm{PI}_{\mathrm{Abs}}, \mathrm{PI}_{\mathrm{Total}}\right)$. Within a production system precipitation affected the ratio Car/total Chl content.
\end{abstract}

Keywords Chlorophyll $a$ fluorescence $\cdot$ Chlorophyll $b / a$ ratio $\cdot$ OJIP transient $\cdot$ Solanum tuberosum $\mathrm{L}$

Anna J. Keutgen

anna.keutgen@boku.ac.at

Extended author information available on the last page of the article 


\section{Introduction}

Potato tubers are among the most important staple crops, which supply not only metabolic energy in the form of carbohydrates, but also additional valuable compounds. The nutritional value of potato tubers is characterised by the presence of essential amino acids (especially lysine) and their fatty acid profile, high starch content, dietary fibre and ascorbic acid as well as a low concentration of fats. Potato tubers also contain important amounts of bioactive compounds and antioxidants, including vitamin $\mathrm{C}$, phenolic acids, carotenoids and flavonoids (Reddivari et al. 2007).

Even if potato breeding nowadays focuses on tuber quality, yield still represents an important aspect that has to be kept in mind during breeding programs. The Plant Breeding and Acclimatization Institute (IHAR-PIB) in Młochów, Poland, has bred seven new tetraploid clones with promising tuber quality traits. These clones were compared with three conventional cultivars ('Jelly', 'Satina', 'Tajfun') with respect to their effectiveness of the photosynthetic system and tuber yield under organic and integrated fertilisation. All seven new tetraploid clones are vegetatively propagated hybrids derived from crossbreeding programs between selections of IHAR-PIB and registered potato cultivars. Plants were cultivated under conditions that are representative of current practices at four experimental stations in Poland. At two of them, potato plants were fertilised organically (Radzików, Chwałowice); at the other two (Młochów, Boguchwała), integrated management was applied in order to determine how these two agricultural practices influence the effectiveness of the photosynthetic system. Another important aspect is to what extent the productivity of potato depends on additional, local environmental factors. Therefore, in the present 3-year study, the general effects of organic and integrated fertilisation and differences in nitrogen supply and precipitation on potato tuber yield were assessed.

Recent studies have shown that the measurement of Chl $a$ fluorescence of photosystem (PS) II represents a significant improvement in the assessment of agricultural productivity and a powerful tool in agricultural, environmental and ecological studies (Kalaji et al. 2016). Under natural conditions, plants are exposed to many adverse environmental stress factors. These cause acclimatisation of the photosynthetic apparatus, which, as a consequence, affects plant development, growth, productivity and yield quantity and quality. Photosynthesis is particularly sensitive to environmental constraints (Kalaji et al. 2012), making Chl $a$ fluorescence measurements an important component of studies on the suitability of potato cultivars for organic and integrated production systems. Because Chl $a$ fluorescence kinetics represent a helpful tool for characterising differences among cultivars in their photosynthetic system (Kalaji et al. 2011a), this rapid and non-destructive technique was selected to compare the ten potato clones and cultivars. Due to the substantial role of photosynthesis in carbon metabolism, differences in Chl $a$ fluorescence should reflect and contribute to differences in tuber yield. Chl fluorescence measurements should be complemented with analyses of leaf Chl content (either destructively or non-destructively using a reflectance-based technique) and, as in the present study, with the analysis of yield-relevant parameters, if these are important for the selection of new commercial cultivars. Phenotyping of Chl $a$ fluorescence characteristics represents a promising practice in breeding programs aimed at finding physiological mechanisms related to yield and environmental stress resistance (Kalaji et al. 2011a, b; Brestic et al. 2012; Zivcak et al. 2014). 
The assessment of the potato clones and cultivars represents a complex approach because different kinds of variables have to be combined. For this reason, a multidimensional comparative analysis (MCA) is introduced which can examine complex phenomena described by two or more variables. Using MCA, two categories of problems can be solved: similarity studies using the methods of classification and ranking studies with the use of linear ordering methods.

\section{Materials and Methods}

The 3-year study (2014-2016) used seven tetraploid potato (Solanum tuberosum L.) clones ('13-VIII-10', '13-VIII-27', '13-VIII-45', '13-VIII-49', '13-VIII-50', '13-VIII60', 'TG-97-403') of the IHAR-PIB (Poland) and three conventional cultivars ('Jelly', 'Satina', 'Tajfun'), which were originally selected for their tuber carotenoid content. All the tetraploid genotypes represented vegetatively propagated hybrids of a crossbreeding program with selection at the IHAR-PIB and established potato cultivars. Experiments were conducted at four experimental stations in Poland with two of them fertilised organically (Radzików, Chwałowice) and the other two according to integrated management (Młochów, Boguchwała). In each location, the potatoes were planted in a randomised complete block design, with two replicates and ten-plant plots (plus two plants at the margin of each side of the field), at the end of April and harvested at the end of August. After tuber harvest, fresh weight was determined. Then, tubers were cut in small pieces, frozen, stored at $-18{ }^{\circ} \mathrm{C}$ and finally freeze-dried in order to determine dry weight and water content. Soil type, fertilisation and measures of plant protection are summarised for each locality and year of experiment in Table 1. For Młochów and Boguchwała, the amounts of fertilizer supplied were determined by the results of previously performed soil analyses, which were $0.063 \pm 0.004,0.056 \pm 0.001$ and $0.044 \pm 0.001 \mathrm{~g} \mathrm{~N} \mathrm{~kg}^{-1}$ soil at Młochów in 2014, 2015 and 2016, respectively, and $0.120 \pm 0.006,0.114 \pm 0.001$ and $0.115 \pm 0.001 \mathrm{~g} \mathrm{~N} \mathrm{~kg}^{-1}$ at Boguchwała in 2014, 2015 and 2016, respectively. The analyses for the other two sites were $0.088 \pm 0.016,0.063$ \pm 0.001 and $0.085 \pm 0.001 \mathrm{~g} \mathrm{~N} \mathrm{~kg}^{-1}$ at Chwałowice in 2014, 2015 and 2016, respectively, and $0.100 \pm 0.006,0.068 \pm 0.001$ and $0.068 \pm 0.001 \mathrm{~g} \mathrm{~N} \mathrm{~kg}^{-1}$ at Radzików in 2014, 2015 and 2016, respectively. Total soil nitrogen content of dried samples was determined by the Kjeldahl distillation and titration method according to the research procedure (PB) 37 ed. 3 dated 15/10/2009 (Trawczyński 2015). At both localities with integrated production, Młochów and Boguchwała, different amounts of nitrogen were supplied (Table 1). This experimental set-up was chosen in order to discuss effects with respect to the relative influence of the production system itself and the available nitrogen content.

The photosynthetic capacity of the clones and cultivars was assessed using Chl fluorescence measurements with the Pocket PEA Rapid Screening Chlorophyll Fluorimeter of Hansatech Instruments Ltd. (Norfolk, United Kingdom). Chl $a$ fluorescence was measured at the basal part of the terminal leaflet of the youngest completely expanded leaf of each plant, usually the third-, and rarely the second-youngest. Leaflets were dark-adapted with a leaf clip for $30 \mathrm{~min}$, and then, the Kautsky induction curves were recorded by applying a saturating light pulse of white light. The data were analysed in line with Strasser et al. $(2000,2004,2010)$. Measurements were performed 

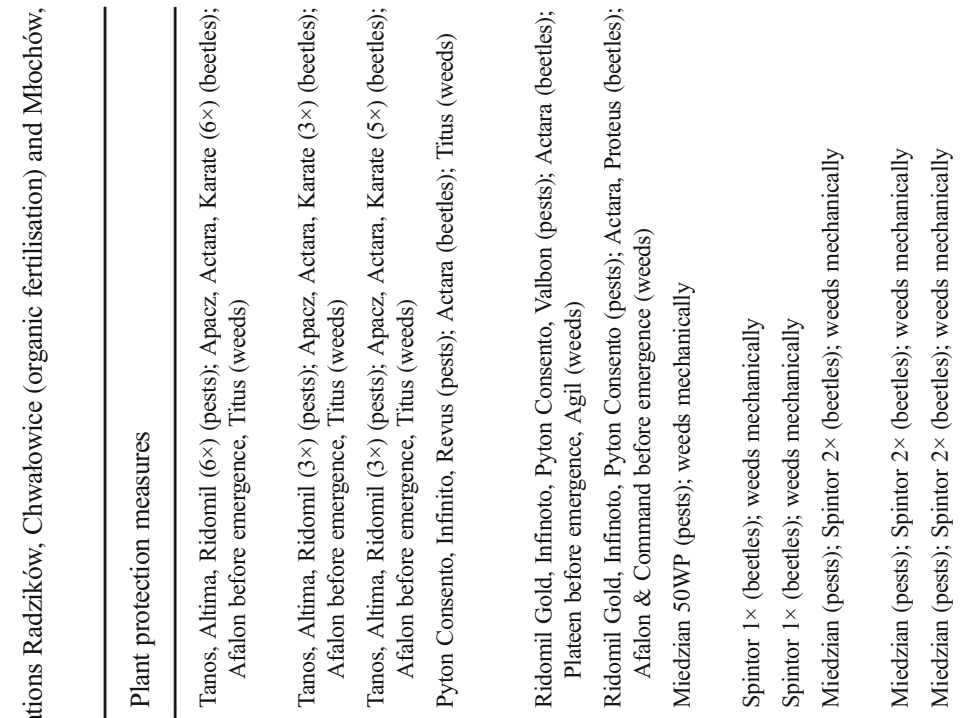

政

है

"0

$\sum$ का के $\sum$ 
on the 10th and 11th July 2014, the 22nd and 23rd June 2015 and 27th and 28th June 2016, respectively, in the interval 'end of the principal growth stage 5 (59)' to 'beginning of the principal growth stage 6 (61)' according to $\mathrm{BBCH}$ growth stage scale potato (Von Hack et al. 1993). On these dates, the photosynthetic capacities of the plants were evaluated under near-optimal environmental conditions.

The interpretation of Chl fluorescence is usually based on the hypothesis that fluorescence is determined by the redox state of the first quinone electron acceptor of PSII $\left(\mathrm{Q}_{\mathrm{A}}\right)$; hence, the net concentration of $\mathrm{Q}_{\mathrm{A}}{ }^{-}$should be related to $\mathrm{Chl} a$ fluorescence yield (Govindjee 2004; Kalaji et al. 2011a). At the 'O' level of Chl fluorescence (or at $\mathrm{F}_{0}$ in another terminology), all $\mathrm{Q}_{\mathrm{A}}$ is considered to be in the oxidised state. The reaction centres (RCs) of PSII are open at $\mathrm{F}_{0}$, and hence, photochemical processes operate at the maximum level. By contrast, when $\mathrm{Chl} a$ fluorescence is maximal $\left(\mathrm{F}_{\mathrm{m}}\right)$, all RC of PSII are closed and the first quinone electron acceptor of PSII is in the reduced state $\left(\mathrm{Q}_{\mathrm{A}}^{-}\right)$. It is hypothesised that $\mathrm{F}_{\mathrm{m}}$ is accompanied by a traffic jam of electrons at the electron acceptor side of PSI, resulting in a minimum of photochemical processes (Govindjee 2004; Kalaji et al. 2011a).

Strasser et al. in their pioneering works $(2000,2004,2010)$ developed the so-called 'OJIP' analysis, where 'O', 'J', 'I' and 'P' define specific inflexion points of the measured curves. This analysis offers simple equations for energy fluxes for light absorption (ABS), trapping of excitation energy (TR) and electron transport (ET, RE) as well as quantum yields and efficiencies $\left(\varphi_{\mathrm{P} 0}, \psi_{\mathrm{E} 0}, \varphi_{\mathrm{E} 0}, \delta_{\mathrm{R} 0}, \varphi_{\mathrm{R} 0}\right)$, characterising energy absorption by PSII antenna pigments, energy trapping for the reduction of pheophytin and $\mathrm{Q}_{\mathrm{A}}$, electron transport after $\mathrm{Q}_{\mathrm{A}}^{-}$to intersystem electron acceptors, and reduction of electron acceptors at the PSI acceptor side (Table 2). Because Chl $a$ fluorescence kinetics represent a helpful tool for characterising differences among cultivars in their photosynthetic system (Kalaji et al. 2011a), this rapid and nondestructive technique was selected to compare the ten potato clones and cultivars. Due to the substantial role of photosynthesis in carbon metabolism, differences in Chl $a$ fluorescence should contribute to differences in tuber yield.

Immediately after measurements of $\mathrm{Chl} a$ fluorescence, leaves were harvested, placed in a cool-box and transported to the laboratory for pigment analyses. These leaf samples were frozen at $-18{ }^{\circ} \mathrm{C}$, freeze-dried and used for the spectrophotometric analyses of Chl and carotenoid contents in line with Wellburn (1994) using methanol as a solvent.

Data analysis was performed with the IBM SPSS STATISTICS version 21 (2017). Because the data were neither normally distributed according to Kolmogorov-Smirnov and Shapiro-Wilk tests nor did the Levene test indicate variance homogeneity, the results of the measurements were compared by nonparametric tests. Mann-WhitneyWilcoxon tests were used to compare single measurements and the significance level was adjusted in line with Bonferroni $(P<\alpha /$ n with $\alpha=0.05$ and $n=4$ for locality or $=$ 10 for clone or cultivar).

The final characterisation of the photosynthetic system of the tested clones and cultivars was evaluated using multidimensional comparative analysis (MCA), which is based on the comparison of multivariate objects (Grabiński et al. 1989; Mierowska 1996). For this purpose, parameters characterising the photosynthetic pigments and Chl fluorescence were evaluated separately after calculating the mean values from all measurements at the four localities collected during the 3 years of experiments. Using 
Table 2 Abbreviations and explanations of the Chl fluorescence parameters calculated from the OJIP measurements

\begin{tabular}{|c|c|}
\hline Parameter & Meaning \\
\hline $\mathrm{RC} / \mathrm{CS}_{\mathrm{m}}$ & Measure of the density of the reaction centres (RCs) \\
\hline $\mathrm{ABS} / \mathrm{RC}$ & Absorbed photons/energy per RC \\
\hline $\mathrm{TR}_{0} / \mathrm{RC}$ & Trapped energy per $\mathrm{RC}$ leading to $\mathrm{Q}_{\mathrm{A}}$ reduction \\
\hline $\mathrm{DI}_{0} / \mathrm{RC}$ & Lost energy per RC \\
\hline $\mathrm{ET}_{0} / \mathrm{RC}$ & Electron transport flux per $\mathrm{RC}$ further than $\mathrm{Q}_{\mathrm{A}}^{-}$ \\
\hline $\mathrm{RE}_{0} / \mathrm{RC}$ & Electron flux reducing end electron acceptors at the PSI acceptor side per RC \\
\hline $\mathrm{F}_{0}$ & Dark fluorescence \\
\hline $\mathrm{F}_{\mathrm{m}}$ & Maximum fluorescence of a dark-adapted leaf \\
\hline$\varphi_{\mathrm{P} 0}$ & Maximum quantum yield for primary photochemistry \\
\hline$\psi_{\mathrm{E} 0}$ & Probability that an electron moves further than $\mathrm{Q}_{\mathrm{A}}^{-}$ \\
\hline$\varphi_{\mathrm{E} 0}$ & Quantum yield for electron transport \\
\hline$\delta_{\mathrm{R} 0}$ & $\begin{array}{l}\text { Probability with which an electron from the intersystem electron carriers is transferred to } \\
\text { reduce end electron acceptors at the PSI acceptor side }\end{array}$ \\
\hline$\varphi_{\mathrm{R} 0}$ & Quantum yield for the reduction of end electron acceptors at the PSI acceptor side \\
\hline $\mathrm{PI}_{\mathrm{Abs}}$ & $\begin{array}{l}\text { Absolute performance index characterising the energy conservation from photons absorbed } \\
\text { by PSII to the reduction of intersystem electron acceptors }\end{array}$ \\
\hline $\mathrm{PI}_{\text {Total }}$ & $\begin{array}{l}\text { Total performance index characterising the energy conservation from photons absorbed by } \\
\text { PSII to the reduction of end electron acceptors at the PSI acceptor side }\end{array}$ \\
\hline
\end{tabular}

MCA, the genotypes were hierarchised and the method of linear ordering of the investigated objects was applied. A matrix was created implementing the diagnostic variables for each genotype. The procedure used is described in detail in Chrzanowska (2017); however, her final step 4 was modified and the normalisation of the measure was carried out using the following formula to calculate the MCA-variables:

$$
\mathrm{MCA}_{\mathrm{i}}=\mathrm{o}_{\mathrm{i}} /(\overline{\mathrm{o}}+2 \times \mathrm{SD}),
$$

where $\mathrm{O}_{\mathrm{i}}$ represents the distance of each object from the pattern, $\bar{o}$ is the mean value of all objects $\mathrm{O}_{\mathrm{i}}$ and $\mathrm{SD}$ is their standard deviation.

These MCA variables are the main criterion for organising the examined genotypes. Values vary between 0 and 1 , and the smaller the MCA variables, the better the 'leaf pigments' and the 'Chl fluorescence' of the genotype is rated. During the creation of the synthetic measures, the assessed parameters were assigned as positively or negatively affecting tuber yield, which is here considered the goal for an optimisation of the photosynthetic system. So-called 'stimulants' are those characteristics where larger values are more desirable, whereas so-called 'de-stimulants' are parameters where smaller values are preferred. For the sake of completeness, it should be mentioned that 'nominants' are features which are characterised by an optimum value, the so-called 'nominal value', or values within a certain range. For the photosynthetic pigments, the leaf contents of total Chl, Chl $a, \mathrm{Chl} b$ and Car, as well as the ratios Chl b/a and Car/ total Chl, were selected and for the evaluation of the electron transport, the parameters 
$\mathrm{RC} / \mathrm{CS}_{\mathrm{m}}, \mathrm{ABS} / \mathrm{RC}, \mathrm{TR}_{0} / \mathrm{RC}, \mathrm{ET}_{0} / \mathrm{RC}, \mathrm{RE}_{0} / \mathrm{RC}, \mathrm{DI}_{0} / \mathrm{RC}, \mathrm{F}_{0}$ and $\mathrm{F}_{\mathrm{m}}$, as well as the efficiencies $\varphi_{\mathrm{P} 0}, \psi_{\mathrm{E} 0}, \varphi_{\mathrm{E} 0}, \delta_{\mathrm{R} 0}$ and $\varphi_{\mathrm{R} 0}$ and performance indices $\left(\mathrm{PI}_{\mathrm{Abs}}, \mathrm{PI}_{\mathrm{Total}}\right)$, were tested (Table 2).

\section{Results and Discussion}

\section{Effect of Locality and Production System}

Temperature differences among localities were small (Figs. 1, 2, 3 and 4) with the mean values of the 3 years lowest at Chwałowice $\left(14.4^{\circ} \mathrm{C}\right)$, intermediate at Boguchwała and Młochów $\left(14.5^{\circ} \mathrm{C}\right)$ and highest at Radzików $\left(14.7^{\circ} \mathrm{C}\right)$. Precipitation varied among localities and years (Figs. 1, 2, 3 and 4) with the mean precipitation highest at Chwałowice, followed closely by Boguchwała. It was intermediate at Młochów and lowest at Radzików (Table 3). Nitrogen content was highest in the soil of Boguchwała, followed by Radzików and Chwałowice, while the content was lowest in Młochów (Table 3). Tuber yield and tuber dry weight were similar among the localities Młochów, Boguchwała and Radzików, but significantly lower at Chwałowice. By contrast, tuber water content was significantly lower at Młochów, but similar among Boguchwała, Radzików and Chwałowice (Table 3). Yield parameters were not consistently related to differences in soil nitrogen content, the production system or mean precipitation. Tuber dry weight was slightly higher under integrated production, but within each production system a high precipitation tended to reduce tuber dry weight. A lower yield under organic cultivation was also reported by Maggio et al. (2008), who found a reduction of $25 \%$ in fresh-weight marketable yield compared to integrated production at the experimental farm of the University of Naples (Italy) using the potato cultivars Agria and Merit.

The analysis of leaf pigments revealed significant differences among localities, which, in most instances, reflected significant differences between organic and

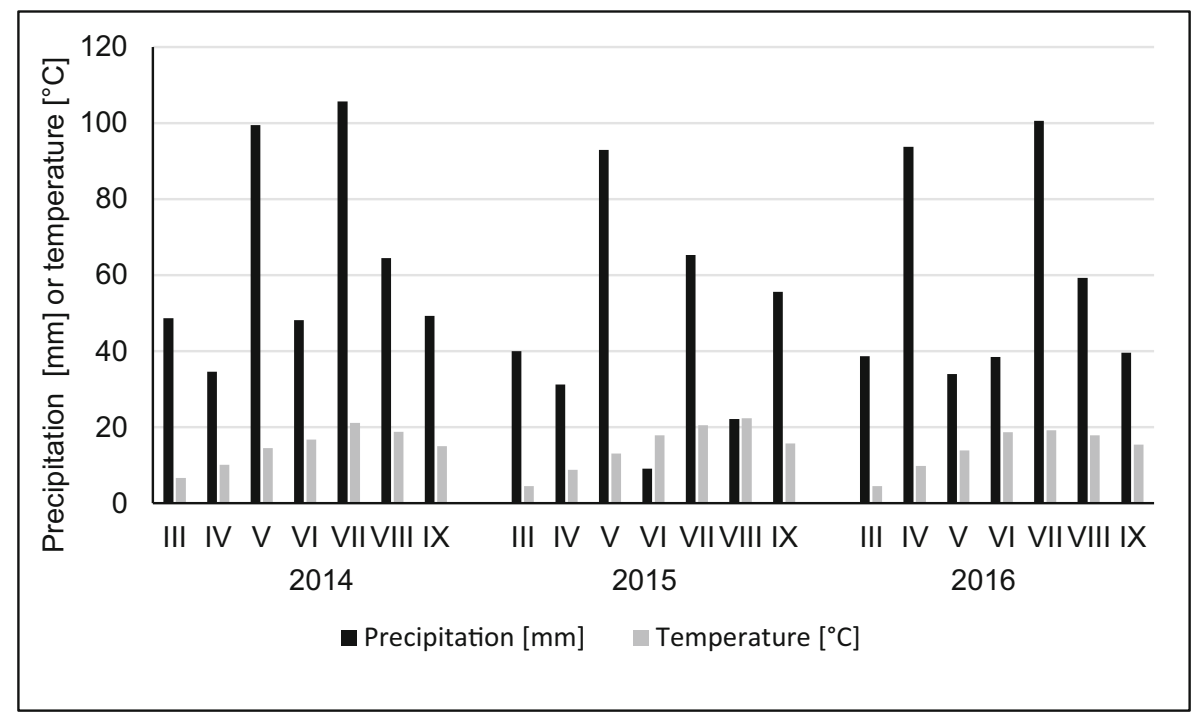

Fig. 1 Precipitation and temperature from March to September at Boguchwała during the years 2014, 2015 and 2016 


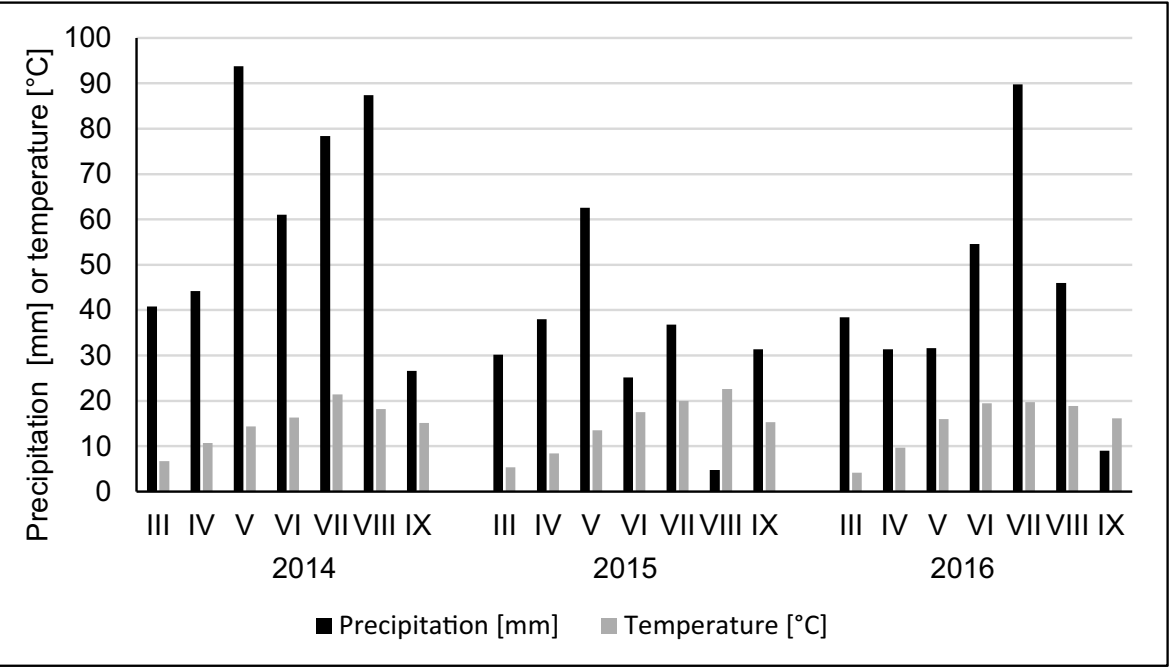

Fig. 2 Precipitation and temperature from March to September at Radzików during the years 2014, 2015 and 2016

integrated fertilisation (Table 4). Organic fertilisation was accompanied by lower contents of total Chl (14.2 vs. $\left.20.6 \mathrm{mg} \mathrm{g}^{-1} \mathrm{DM}\right), \mathrm{Chl} a\left(10.1\right.$ vs. $\left.14.3 \mathrm{mg} \mathrm{g}^{-1} \mathrm{DM}\right)$, Chl $b$ (4.1 vs. $\left.6.3 \mathrm{mg} \mathrm{g}^{-1} \mathrm{DM}\right)$ and Car ( 3.7 vs. $\left.5.2 \mathrm{mg} \mathrm{g}^{-1} \mathrm{DM}\right)$ in potato leaves. The $31 \%$ lower total $\mathrm{Chl}$ content suggests interpretation of the results as indicative of a suboptimal availability of nitrogen in the plants fertilised organically, because a low Chl content is generally coupled with a low nitrogen content in leaves (Vos and Bom 1993; Mauromicale et al. 2006). However, a comparison of soil nitrogen content indicates that the highest and lowest contents were found in integrated production due to different amounts of nitrogen supplied (Table 1), proving that it is not the soil nitrogen content but the production system that limits leaf $\mathrm{Chl}$ content and, hence, the availability of

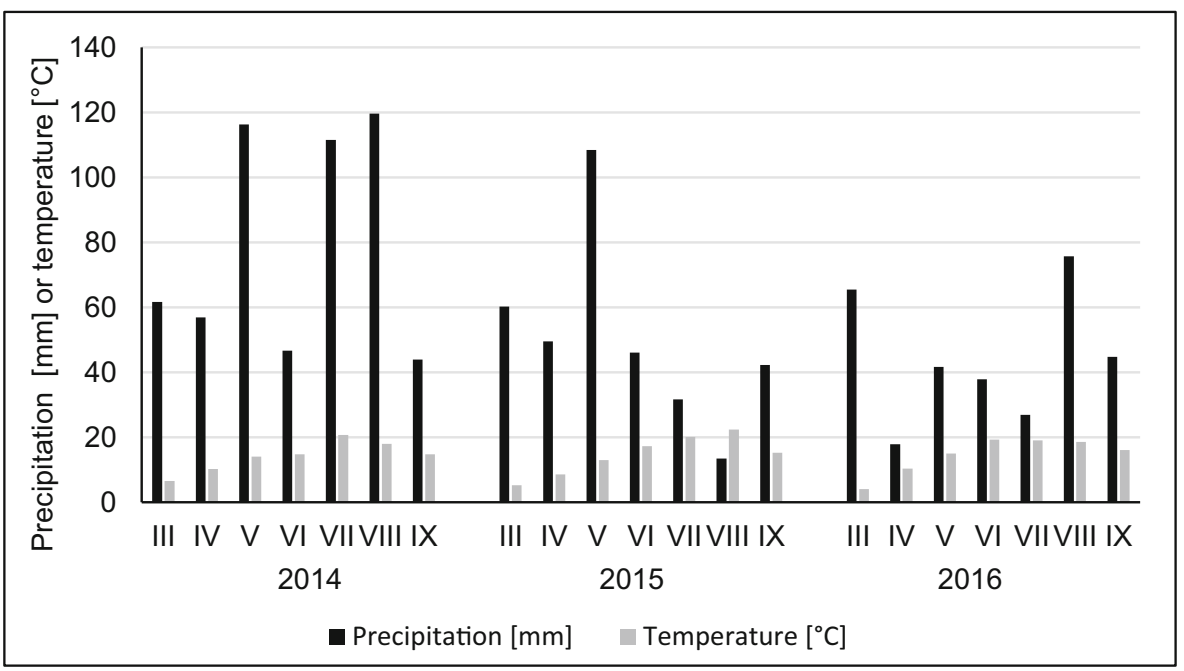

Fig. 3 Precipitation and temperature from March to September at Chwałowice during the years 2014, 2015 and 2016 


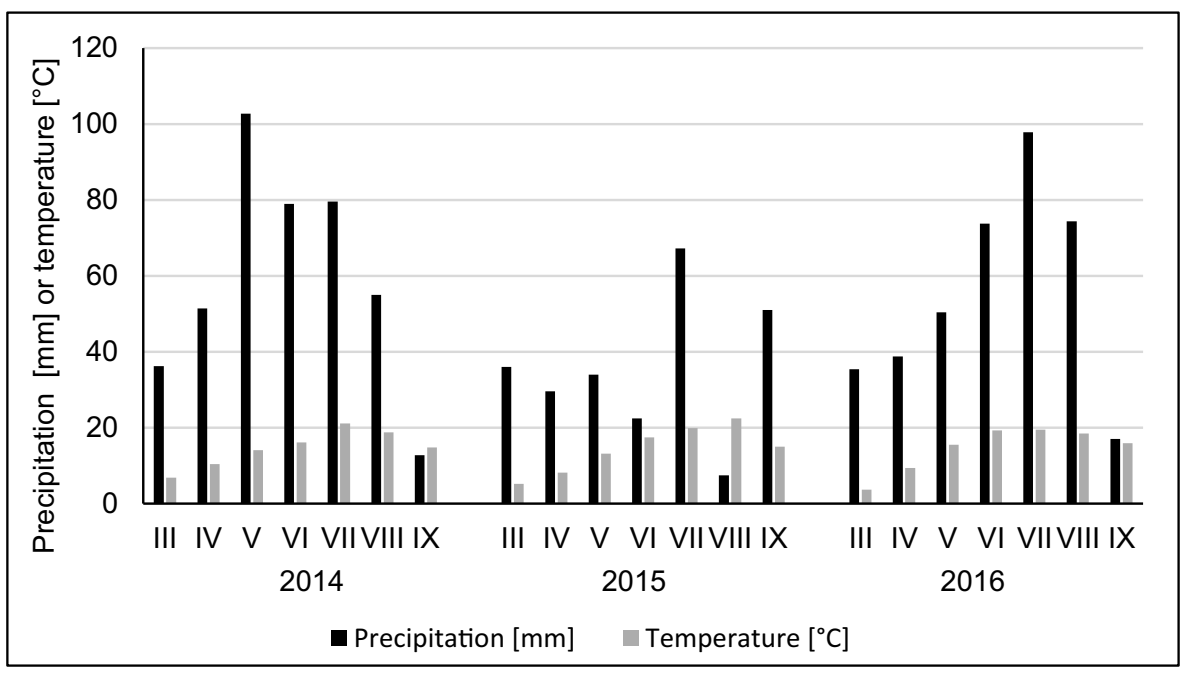

Fig. 4 Precipitation and temperature from March to September at Młochów during the years 2014, 2015 and 2016

nitrogen. Thus, the present result confirms Maggio et al. (2008) and Ierna and Parisi (2014) that organic fertilisation does not provide nitrogen in a form that is as readily accessible to plants as from conventional fertilizers.

Table 3 Differences in soil nitrogen content after harvest, mean precipitation during the cultivation period (March-September), potato tuber yield, water content and dry weight, among different localities. 1. Młochów, 2. Boguchwała, 3. Radzików, 4. Chwałowice. Different letters indicate significant differences by MannWhitney-Wilcoxon tests

\begin{tabular}{|c|c|c|c|c|}
\hline & Mean $\pm \mathrm{SD}$ & Soil nitrogen content & Fertilisation & Precipitation \\
\hline Soil $\mathrm{N}$ content ( $\mathrm{g} \mathrm{kg}^{-1}$ soil) & $\begin{array}{l}\text { 1. } 0.55 \pm 0.09 \mathrm{c} \\
\text { 2. } 1.16 \pm 0.04 \mathrm{a} \\
\text { 3. } 0.79 \pm 0.17 \mathrm{~b} \\
\text { 4. } 0.79 \pm 0.14 \mathrm{~b}\end{array}$ & & $\begin{array}{l}\text { integrated } \\
\text { integrated } \\
\text { organic } \\
\text { organic }\end{array}$ & $\begin{array}{l}\text { "medium" } \\
\text { "higher" } \\
\text { "lower" } \\
\text { "higher" }\end{array}$ \\
\hline Mean precipitation (mm) & $\begin{array}{l}\text { 1. } 351 \pm 90 \\
\text { 2. } 390 \pm 68 \\
\text { 3. } 321 \pm 103 \\
\text { 4. } 406 \pm 132\end{array}$ & $\begin{array}{l}\text { lower } \\
\text { higher } \\
\text { medium } \\
\text { medium }\end{array}$ & $\begin{array}{l}\text { integrated } \\
\text { integrated } \\
\text { organic } \\
\text { organic }\end{array}$ & \\
\hline Tuber yield (t/ha) & $\begin{array}{l}\text { 1. } 34.2 \pm 7.7 \mathrm{a} \\
\text { 2. } 37.3 \pm 10.9 \mathrm{a} \\
\text { 3. } 35.5 \pm 12.4 \mathrm{a} \\
\text { 4. } 14.5 \pm 3.4 \mathrm{~b}\end{array}$ & $\begin{array}{l}\text { lower } \\
\text { higher } \\
\text { medium } \\
\text { medium }\end{array}$ & $\begin{array}{l}\text { integrated } \\
\text { integrated } \\
\text { organic } \\
\text { organic }\end{array}$ & $\begin{array}{l}\text { "medium" } \\
\text { "higher" } \\
\text { "lower" } \\
\text { "higher" }\end{array}$ \\
\hline Tuber water content $(\%)$ & $\begin{array}{l}1.78 .3 \pm 2.8 \mathrm{~b} \\
\text { 2. } 81.0 \pm 3.2 \mathrm{a} \\
\text { 3. } 80.9 \pm 4.1 \mathrm{a} \\
\text { 4. } 81.4 \pm 4.3 \mathrm{a}\end{array}$ & $\begin{array}{l}\text { lower } \\
\text { higher } \\
\text { medium } \\
\text { medium }\end{array}$ & $\begin{array}{l}\text { integrated } \\
\text { integrated } \\
\text { organic } \\
\text { organic }\end{array}$ & $\begin{array}{l}\text { "medium" } \\
\text { "higher" } \\
\text { "lower" } \\
\text { "higher" }\end{array}$ \\
\hline Tuber dry mass (t/ha) & $\begin{array}{l}\text { 1. } 7.42 \pm 2.61 \mathrm{a} \\
\text { 2. } 7.09 \pm 3.80 \mathrm{a} \\
\text { 3. } 6.78 \pm 6.43 \mathrm{a} \\
\text { 4. } 2.70 \pm 1.71 \mathrm{~b}\end{array}$ & $\begin{array}{l}\text { lower } \\
\text { higher } \\
\text { medium } \\
\text { medium }\end{array}$ & $\begin{array}{l}\text { integrated } \\
\text { integrated } \\
\text { organic } \\
\text { organic }\end{array}$ & $\begin{array}{l}\text { "medium" } \\
\text { "higher" } \\
\text { "lower" } \\
\text { "higher" }\end{array}$ \\
\hline
\end{tabular}


Table 4 Differences in leaf pigment content among studied localities. 1. Młochów, 2. Boguchwała (both integrated cultivation), 3. Radzików, 4. Chwałowice (organic fertilisation). Different letters indicate significant differences by Mann-Whitney-Wilcoxon tests

\begin{tabular}{|c|c|c|c|c|}
\hline & Mean \pm SD & Soil nitrogen content & Fertilisation & Precipitation \\
\hline Total Chl $\left(\mathrm{mg} \mathrm{g}^{-1} \mathrm{DM}\right)$ & $\begin{array}{l}1.21 .40 \pm 7.02 \mathrm{a} \\
2.19 .84 \pm 7.31 \mathrm{~b} \\
3.13 .81 \pm 6.37 \mathrm{c} \\
4.14 .66 \pm 7.07 \mathrm{c}\end{array}$ & $\begin{array}{l}\text { lower } \\
\text { higher } \\
\text { medium } \\
\text { medium }\end{array}$ & $\begin{array}{l}\text { integrated } \\
\text { integrated } \\
\text { organic } \\
\text { organic }\end{array}$ & $\begin{array}{l}\text { "medium" } \\
\text { "higher" } \\
\text { "lower" } \\
\text { "higher" }\end{array}$ \\
\hline Chl $a\left(\mathrm{mg} \mathrm{g}^{-1} \mathrm{DM}\right)$ & $\begin{array}{l}\text { 1. } 14.97 \pm 4.56 \mathrm{a} \\
\text { 2. } 13.66 \pm 4.84 \mathrm{~b} \\
\text { 3. } 9.83 \pm 4.39 \mathrm{c} \\
\text { 4. } 10.41 \pm 4.95 \mathrm{c}\end{array}$ & $\begin{array}{l}\text { lower } \\
\text { higher } \\
\text { medium } \\
\text { medium }\end{array}$ & $\begin{array}{l}\text { integrated } \\
\text { integrated } \\
\text { organic } \\
\text { organic }\end{array}$ & $\begin{array}{l}\text { "medium" } \\
\text { "higher" } \\
\text { "lower" } \\
\text { "higher" }\end{array}$ \\
\hline Chl $b\left(\mathrm{mg} \mathrm{g}^{-1} \mathrm{DM}\right)$ & $\begin{array}{l}\text { 1. } 6.43 \pm 2.52 \mathrm{a} \\
\text { 2. } 6.18 \pm 2.56 \mathrm{a} \\
\text { 3. } 3.98 \pm 2.02 \mathrm{~b} \\
\text { 4. } 4.24 \pm 2.15 \mathrm{~b}\end{array}$ & $\begin{array}{l}\text { lower } \\
\text { higher } \\
\text { medium } \\
\text { medium }\end{array}$ & $\begin{array}{l}\text { integrated } \\
\text { integrated } \\
\text { organic } \\
\text { organic }\end{array}$ & $\begin{array}{l}\text { "medium" } \\
\text { "higher" } \\
\text { "lower" } \\
\text { "higher" }\end{array}$ \\
\hline Chl $b / a$ & $\begin{array}{l}\text { 1. } 0.421 \pm 0.050 \mathrm{~b} \\
\text { 2. } 0.446 \pm 0.056 \mathrm{a} \\
\text { 3. } 0.399 \pm 0.046 \mathrm{~d} \\
\text { 4. } 0.406 \pm 0.037 \mathrm{c}\end{array}$ & $\begin{array}{l}\text { lower } \\
\text { higher } \\
\text { medium } \\
\text { medium }\end{array}$ & $\begin{array}{l}\text { integrated } \\
\text { integrated } \\
\text { organic } \\
\text { organic }\end{array}$ & $\begin{array}{l}\text { "medium" } \\
\text { "higher" } \\
\text { "lower" } \\
\text { "higher" }\end{array}$ \\
\hline Car (mg g $\left.{ }^{-1} \mathrm{DM}\right)$ & $\begin{array}{l}1.5 .66 \pm 2.82 \mathrm{a} \\
2.4 .84 \pm 2.32 \mathrm{~b} \\
\text { 3. } 3.60 \pm 1.90 \mathrm{c} \\
\text { 4. } 3.81 \pm 2.35 \mathrm{c}\end{array}$ & $\begin{array}{l}\text { lower } \\
\text { higher } \\
\text { medium } \\
\text { medium }\end{array}$ & $\begin{array}{l}\text { integrated } \\
\text { integrated } \\
\text { organic } \\
\text { organic }\end{array}$ & $\begin{array}{l}\text { "medium" } \\
\text { "higher" } \\
\text { "lower" } \\
\text { "higher" }\end{array}$ \\
\hline Car/total Chl & $\begin{array}{l}\text { 1. } 0.262 \pm 0.094 \mathrm{a} \\
\text { 2. } 0.249 \pm 0.076 \mathrm{~b} \\
\text { 3. } 0.271 \pm 0.087 \mathrm{a} \\
\text { 4. } 0.257 \pm 0.073 \mathrm{~b}\end{array}$ & $\begin{array}{l}\text { lower } \\
\text { higher } \\
\text { medium } \\
\text { medium }\end{array}$ & $\begin{array}{l}\text { integrated } \\
\text { integrated } \\
\text { organic } \\
\text { organic }\end{array}$ & $\begin{array}{l}\text { "medium" } \\
\text { "higher" } \\
\text { "lower" } \\
\text { "higher" }\end{array}$ \\
\hline
\end{tabular}

Chl. chlorophyll, Car. carotenoids

Generally, leaf $\mathrm{Chl}$ content is coupled with leaf nitrogen content, and according to the theory of optimal nitrogen partitioning within a leaf, the $\mathrm{Chl} b / a$ ratio is expected to decrease when leaf $\mathrm{N}$ content decreases (Kitajima and Hogan 2003). In principal, this relationship is confirmed by the observation that the Chl b/a ratio is reflected in the impact of the production system such as total $\mathrm{Chl}$ content (Table 4). In addition, the $\mathrm{Chl} b / a$ ratio is, together with the ratio Car/total Chl, also affected by the mean precipitation (Table 4). Within a production system, the $\mathrm{Chl} b / a$ ratio was higher when the precipitation was high. It is generally known that under drought stress, the reduction of $\mathrm{Chl} b$ is greater than that of $\mathrm{Chl}$ $a$, resulting in a decrease in the $\mathrm{Chl} b / a$ ratio. However, the opposite response of the $\mathrm{Chl} b / a$ ratio has also been documented (Ashraf and Harris 2013). It is, therefore, suggested to interpret the dependency of the $\mathrm{Chl} b / a$ ratio on precipitation as a consequence of a temporarily occurring water shortage at Młochów and Radzików.

The increase in the ratio Car/total Chl under a medium or low precipitation regime within a production system may be interpreted similarly. Carotenoids not only contribute to light harvesting, but they may also contribute to quenching of excessive light energy (Demmig-Adams and Adams III 1996). This characteristic of the xanthophyll cycle may be involved in the case of an imbalance of water and light availability and results in an increase of carotenoids content relative to total Chl content if water 
becomes a temporarily limiting factor. In addition, carotenoids are also present in the plant cellular membranes, where they protect from light-dependent oxidative damage. The role of carotenoids in scavenging reactive oxygen species has been studied by Davison et al. (2002) and is summarised in Ashraf and Harris (2013).

The light-use efficiency of the photosynthetic system is difficult to predict, because the partitioning of leaf $\mathrm{N}$ between ribulose bisphosphate carboxylase oxygenase (Rubisco) and the light harvesting complex consisting of Chl and attached proteins is likely to be genotype-dependent (Veres et al. 2017), balancing the harvesting of light energy and its utilisation in the dark reactions of photosynthesis in relation to environmental factors such as water availability. For the studied potato clones and cultivars, the Chl $a$ fluorescence parameters, such as $\mathrm{RC} / \mathrm{CS}_{\mathrm{m}}, \varphi_{\mathrm{P} 0}, \varphi_{\mathrm{E} 0}, \varphi_{\mathrm{R} 0}, \mathrm{PI}_{\mathrm{Abs}}$ and $\mathrm{PI}_{\mathrm{Total}}$, followed in most cases the soil nitrogen content (Table 5), ABS/RC was inversely correlated with soil nitrogen content. The listed parameters best characterise the efficiency of the light reactions. While it is not unexpected that they follow soil nitrogen content, it is worth noting that leaf $\mathrm{Chl}$ content, in contrast, is strongly affected by the production system (Table 4). However, $\mathrm{F}_{\mathrm{m}}$ is also influenced by the production system (Table 5) and $F_{m}$ has indeed been reported by Miranda et al. (1981) and Netto et al. (2005) as proportional to total chlorophyll content. However, Netto et al. (2005) observed a linear relationship between total $\mathrm{Chl}$ content and $\mathrm{F}_{\mathrm{m}}$ only up to a $\mathrm{Chl}$ content of about $150-200 \mu \mathrm{mol} \mathrm{m}{ }^{-2}$. For a further increase in total Chl content, a stable behaviour in the $\mathrm{F}_{\mathrm{m}}$ values was observed.

It was suggested previously to interpret the relationship between $\mathrm{Chl}$ content and production system as indicative of a sub-optimal availability of nitrogen in the plants fertilised organically. However, the observed relationship of the majority of the chlorophyll fluorescence parameters with soil nitrogen content questions this general conclusion. If these chlorophyll fluorescence parameters are not related by the production system to leaf $\mathrm{Chl}$ content, they may be influenced by other compounds affected by the soil nitrogen content, for example, the activity of Rubisco, which is the dominating enzyme of leaves. If this hypothesis is correct, the effectiveness of the light reactions of photosynthesis should be strongly coupled to the energy needs of the dark reactions of photosynthesis. Since neither leaf nitrogen content nor Rubisco activity were assessed in the present study, it remains unsettled, in what different ways the soil nitrogen content and the production system affected leaf nitrogen and Chl contents as well as chlorophyll fluorescence and Rubisco activity.

If chlorophyll fluorescence and Rubisco activity were well coordinated, it would be reasonable that the density of the reaction centres $\left(\mathrm{RC} / \mathrm{CS}_{\mathrm{m}}\right)$ is controlled by Rubisco activity. Likewise, the measure of absorbed photons per RC (ABS/RC) may be inversely correlated with Rubisco activity and $\mathrm{RC} / \mathrm{CS}_{\mathrm{m}}$. In a light-exposed location as in the case of potato production, there is always the danger of an excessive amount of light energy transferred to a single RC. As a consequence, the density of RCs may be increased while the absorbed energy per RC may be reduced in order to protect the light harvesting system and optimise light harvesting. Further steps to balance electron transport to the end electron acceptors at the PSI acceptor side are best characterised by the efficiencies $\varphi_{\mathrm{P} 0}, \psi_{\mathrm{E} 0}, \varphi_{\mathrm{E} 0}, \delta_{\mathrm{R} 0}$ and $\varphi_{\mathrm{R} 0}$. It is worth noting that $\varphi_{\mathrm{P} 0}, \varphi_{\mathrm{E} 0}$ and $\varphi_{\mathrm{R} 0}$ are all related to soil nitrogen content (Table 5), while the single steps $\psi_{\mathrm{E} 0}$ and $\delta_{\mathrm{R} 0}$ cannot be related with certainty to one of the considered factors (soil nitrogen content, cultivation system, precipitation). Since $\varphi_{\mathrm{R} 0}$ is the product of $\varphi_{\mathrm{P} 0}, \psi_{\mathrm{E} 0}$ and $\delta_{\mathrm{R} 0}$, it is 
Table 5 Differences in Chl $a$ fluorescence parameters (for abbreviations, see Table 2) among studied localities. 1. Młochów, 2. Boguchwała (both integrated cultivation), 3. Radzików, 4. Chwałowice (organic fertilisation). Different letters indicate significant differences by Mann-Whitney-Wilcoxon tests

\begin{tabular}{|c|c|c|c|c|}
\hline & Mean \pm SD & Soil nitrogen content & Fertilisation & Precipitation \\
\hline $\mathrm{RC} / \mathrm{CS}_{\mathrm{m}}$ & $\begin{array}{l}\text { 1. } 21,742 \pm 6465 \mathrm{c} \\
\text { 2. } 26,569 \pm 3891 \mathrm{a} \\
\text { 3. } 24,497 \pm 7659 \mathrm{~b} \\
\text { 4. } 23,370 \pm 6571 \mathrm{~b}\end{array}$ & $\begin{array}{l}\text { lower } \\
\text { higher } \\
\text { medium } \\
\text { medium }\end{array}$ & $\begin{array}{l}\text { integrated } \\
\text { integrated } \\
\text { organic } \\
\text { organic }\end{array}$ & $\begin{array}{l}\text { "medium" } \\
\text { "higher" } \\
\text { "lower" } \\
\text { "higher" }\end{array}$ \\
\hline $\mathrm{ABS} / \mathrm{RC}$ & $\begin{array}{l}\text { 1. } 1.680 \pm 0.331 \mathrm{a} \\
\text { 2. } 1.348 \pm 0.203 \mathrm{c} \\
\text { 3. } 1.461 \pm 0.270 \mathrm{~b} \\
\text { 4. } 1.474 \pm 0.223 \mathrm{~b}\end{array}$ & $\begin{array}{l}\text { lower } \\
\text { higher } \\
\text { medium } \\
\text { medium }\end{array}$ & $\begin{array}{l}\text { integrated } \\
\text { integrated } \\
\text { organic } \\
\text { organic }\end{array}$ & $\begin{array}{l}\text { "medium" } \\
\text { "higher" } \\
\text { "lower" } \\
\text { "higher" }\end{array}$ \\
\hline $\mathrm{TR}_{0} / \mathrm{RC}$ & $\begin{array}{l}\text { 1. } 1.292 \pm 0.213 \mathrm{a} \\
\text { 2. } 1.108 \pm 0.156 \mathrm{c} \\
\text { 3. } 1.160 \pm 0.171 \mathrm{~b} \\
\text { 4. } 1.178 \pm 0.153 \mathrm{~b}\end{array}$ & $\begin{array}{l}\text { lower } \\
\text { higher } \\
\text { medium } \\
\text { medium }\end{array}$ & $\begin{array}{l}\text { integrated } \\
\text { integrated } \\
\text { organic } \\
\text { organic }\end{array}$ & $\begin{array}{l}\text { "medium" } \\
\text { "higher" } \\
\text { "lower" } \\
\text { "higher" }\end{array}$ \\
\hline $\mathrm{ET}_{0} / \mathrm{RC}$ & $\begin{array}{l}\text { 1. } 0.629 \pm 0.081 \mathrm{~b} \\
\text { 2. } 0.648 \pm 0.122 \mathrm{ab} \\
\text { 3. } 0.610 \pm 0.092 \mathrm{c} \\
\text { 4. } 0.656 \pm 0.098 \mathrm{a}\end{array}$ & $\begin{array}{l}\text { lower } \\
\text { higher } \\
\text { medium } \\
\text { medium }\end{array}$ & $\begin{array}{l}\text { integrated } \\
\text { integrated } \\
\text { organic } \\
\text { organic }\end{array}$ & $\begin{array}{l}\text { "medium" } \\
\text { "higher" } \\
\text { "lower" } \\
\text { "higher" }\end{array}$ \\
\hline $\mathrm{RE}_{0} / \mathrm{RC}$ & $\begin{array}{l}\text { 1. } 0.333 \pm 0.062 \mathrm{a} \\
\text { 2. } 0.301 \pm 0.039 \mathrm{~b} \\
\text { 3. } 0.304 \pm 0.064 \mathrm{~b} \\
\text { 4. } 0.301 \pm 0.054 \mathrm{~b}\end{array}$ & $\begin{array}{l}\text { lower } \\
\text { higher } \\
\text { medium } \\
\text { medium }\end{array}$ & $\begin{array}{l}\text { integrated } \\
\text { integrated } \\
\text { organic } \\
\text { organic }\end{array}$ & $\begin{array}{l}\text { "medium" } \\
\text { "higher" } \\
\text { "lower" } \\
\text { "higher" }\end{array}$ \\
\hline $\mathrm{F}_{0}$ & $\begin{array}{l}\text { 1. } 7920 \pm 1988 \mathrm{a} \\
\text { 2. } 6258 \pm 1014 \mathrm{c} \\
\text { 3. } 6784 \pm 1554 \mathrm{~b} \\
\text { 4. } 6546 \pm 1202 \mathrm{~b}\end{array}$ & $\begin{array}{l}\text { lower } \\
\text { higher } \\
\text { medium } \\
\text { medium }\end{array}$ & $\begin{array}{l}\text { integrated } \\
\text { integrated } \\
\text { organic } \\
\text { organic }\end{array}$ & $\begin{array}{l}\text { "medium" } \\
\text { "higher" } \\
\text { "lower" } \\
\text { "higher" }\end{array}$ \\
\hline $\mathrm{F}_{\mathrm{m}}$ & $\begin{array}{l}\text { 1. } 35,747 \pm 9740 \mathrm{ab} \\
\text { 2. } 35,466 \pm 5680 \mathrm{a} \\
\text { 3. } 34,475 \pm 9040 \mathrm{~b} \\
\text { 4. } 33,602 \pm 7912 \mathrm{~b}\end{array}$ & $\begin{array}{l}\text { lower } \\
\text { higher } \\
\text { medium } \\
\text { medium }\end{array}$ & $\begin{array}{l}\text { integrated } \\
\text { integrated } \\
\text { organic } \\
\text { organic }\end{array}$ & $\begin{array}{l}\text { "medium" } \\
\text { "higher" } \\
\text { "lower" } \\
\text { "higher" }\end{array}$ \\
\hline$\varphi_{\mathrm{P} 0}$ & $\begin{array}{l}\text { 1. } 0.774 \pm 0.038 \mathrm{c} \\
\text { 2. } 0.823 \pm 0.013 \mathrm{a} \\
\text { 3. } 0.799 \pm 0.033 \mathrm{~b} \\
\text { 4. } 0.802 \pm 0.024 \mathrm{~b}\end{array}$ & $\begin{array}{l}\text { lower } \\
\text { higher } \\
\text { medium } \\
\text { medium }\end{array}$ & $\begin{array}{l}\text { integrated } \\
\text { integrated } \\
\text { organic } \\
\text { organic }\end{array}$ & $\begin{array}{l}\text { "medium" } \\
\text { "higher" } \\
\text { "lower" } \\
\text { "higher" }\end{array}$ \\
\hline$\psi_{\mathrm{E} 0}$ & $\begin{array}{l}\text { 1. } 0.496 \pm 0.085 \mathrm{c} \\
\text { 2. } 0.584 \pm 0.064 \mathrm{a} \\
\text { 3. } 0.530 \pm 0.064 \mathrm{~b} \\
\text { 4. } 0.563 \pm 0.089 \mathrm{a}\end{array}$ & $\begin{array}{l}\text { lower } \\
\text { higher } \\
\text { medium } \\
\text { medium }\end{array}$ & $\begin{array}{l}\text { integrated } \\
\text { integrated } \\
\text { organic } \\
\text { organic }\end{array}$ & $\begin{array}{l}\text { "medium" } \\
\text { "higher" } \\
\text { "lower" } \\
\text { "higher" }\end{array}$ \\
\hline$\varphi_{\mathrm{E} 0}$ & $\begin{array}{l}\text { 1. } 0.386 \pm 0.078 \mathrm{~d} \\
\text { 2. } 0.481 \pm 0.056 \mathrm{a} \\
\text { 3. } 0.424 \pm 0.060 \mathrm{c} \\
\text { 4. } 0.453 \pm 0.080 \mathrm{~b}\end{array}$ & $\begin{array}{l}\text { lower } \\
\text { higher } \\
\text { medium } \\
\text { medium }\end{array}$ & $\begin{array}{l}\text { integrated } \\
\text { integrated } \\
\text { organic } \\
\text { organic }\end{array}$ & $\begin{array}{l}\text { "medium" } \\
\text { "higher" } \\
\text { "lower" } \\
\text { "higher" }\end{array}$ \\
\hline$\delta_{\mathrm{R} 0}$ & $\begin{array}{l}\text { 1. } 0.539 \pm 0.117 \mathrm{a} \\
\text { 2. } 0.478 \pm 0.098 \mathrm{c} \\
\text { 3. } 0.501 \pm 0.090 \mathrm{~b} \\
\text { 4. } 0.470 \pm 0.117 \mathrm{c}\end{array}$ & $\begin{array}{l}\text { lower } \\
\text { higher } \\
\text { medium } \\
\text { medium }\end{array}$ & $\begin{array}{l}\text { integrated } \\
\text { integrated } \\
\text { organic } \\
\text { organic }\end{array}$ & $\begin{array}{l}\text { "medium" } \\
\text { "higher" } \\
\text { "lower" } \\
\text { "higher" }\end{array}$ \\
\hline$\varphi_{\mathrm{R} 0}$ & $\begin{array}{l}\text { 1. } 0.204 \pm 0.048 \mathrm{~b} \\
\text { 2. } 0.226 \pm 0.036 \mathrm{a} \\
\text { 3. } 0.209 \pm 0.030 \mathrm{~b} \\
\text { 4. } 0.206 \pm 0.037 \mathrm{~b}\end{array}$ & $\begin{array}{l}\text { lower } \\
\text { higher } \\
\text { medium } \\
\text { medium }\end{array}$ & $\begin{array}{l}\text { integrated } \\
\text { integrated } \\
\text { organic } \\
\text { organic }\end{array}$ & $\begin{array}{l}\text { "medium" } \\
\text { "higher" } \\
\text { "lower" } \\
\text { "higher" }\end{array}$ \\
\hline $\mathrm{PI}_{\mathrm{Abs}}$ & $1.2 .544 \pm 1.594 \mathrm{~d}$ & lower & integrated & "medium" \\
\hline
\end{tabular}


Table 5 (continued)

\begin{tabular}{lllll}
\hline & Mean $\pm \mathrm{SD}$ & Soil nitrogen content & Fertilisation & Precipitation \\
\hline & $2.5 .252 \pm 1.745 \mathrm{a}$ & higher & integrated & "higher" \\
& $3.3 .586 \pm 1.708 \mathrm{c}$ & medium & organic & "lower" \\
& $4.4 .195 \pm 2.015 \mathrm{~b}$ & medium & "higher" \\
$\mathrm{PI}_{\mathrm{Total}}$ & $1.2 .998 \pm 1.997 \mathrm{c}$ & lower & integrated & "medium" \\
& $2.4 .917 \pm 1.918 \mathrm{a}$ & higher & organic & "higher" \\
& $3.3 .504 \pm 1.573 \mathrm{~b}$ & medium & "lower" \\
& $4.3 .567 \pm 1.665 \mathrm{~b}$ & medium & & "higher" \\
\hline
\end{tabular}

concluded that the relationship between $\varphi_{\mathrm{R} 0}$ and soil nitrogen content is determined by $\varphi_{\mathrm{P} 0}$, the first step of electron transport.

The parameters $\mathrm{RC} / \mathrm{CS}_{\mathrm{m}}, \varphi_{\mathrm{P} 0}, \mathrm{PI}_{\mathrm{Abs}}$ and $\mathrm{PI}_{\text {Total }}$ may be regarded as the most important for the characterisation of $\mathrm{Chl}$ fluorescence. $\mathrm{RC} / \mathrm{CS}_{\mathrm{m}}$, the efficiency of light harvesting, was highest in Boguchwała, intermediate in Radzików and Chwałowice, and smallest in Młochów (Table 5). The efficiency of chlorophyll fluorescence has traditionally been described using the parameters $\varphi_{\mathrm{P} 0} \mathrm{PI}_{\mathrm{Abs}}$ and $\mathrm{PI}_{\text {Total }}$. With respect to these parameters the same ranking was found as in case of $\mathrm{RC} / \mathrm{CS}_{\mathrm{m}}$. However, in case of $\mathrm{PI}_{\mathrm{Abs}}$, potatoes cultivated at Chwałowice performed better than those grown at Radzików, which might reflect an influence of precipitation, which was higher at Chwałowice than at Radzików (Table 5).

\section{Evaluation of the Photosynthetic System of the Potato Clones and Cultivars}

Since the leaf pigment content was mainly affected by the production system and the chlorophyll fluorescence parameters were influenced most by soil nitrogen content, both components of the photosynthetic system were studied separately using MCA.

The analysis, where leaf pigment parameters were related to tuber dry weight, revealed that concentrations of total $\mathrm{Chl}, \mathrm{Chl} a, \mathrm{Chl} b$ and carotenoids were significantly and positively correlated, and hence stimulants (Table 6). The ratios Chl b/a and $\mathrm{Car} /$ total Chl were not related to tuber yield.

From total Chl, Chl $a$, Chl $b$ and Car contents, the MCAs of yield-relevant leaf pigment properties were calculated for cultivars and clones and correlated with their tuber dry weights (probability $=0.002$ ). The ranking from best to worst leaf pigment parameters started with cv. Tajfun, followed by the clones 13-VIII-27, TG-97-403, 13-

Table 6 Pearson correlation coefficient and probability level of the relationships of single $\mathrm{Chl}$ fluorescence parameters and tuber dry weight. Based on these results, the parameters were rated as 'stimulant' or 'de-stimulant' or not related (-)

\begin{tabular}{llll}
\hline Parameter & $\begin{array}{l}\text { Pearson correlation } \\
\text { coefficient }\end{array}$ & Probability & Evaluation \\
\hline Total Chl & 0.852 & 0.002 & Stimulant \\
Chl $a$ & 0.860 & 0.001 & Stimulant \\
Chl $b$ & 0.821 & 0.004 & Stimulant \\
Chl $b / a$ & 0.490 & 0.151 & - \\
Car & 0.824 & 0.003 & Stimulant \\
Car/total Chl & -0.561 & 0.092 & - \\
\hline
\end{tabular}


VIII-50, then cultivars Jelly and Satina, then clones 13-VIII-49, 13-VIII-60 and 13VIII-10 and finally 13-VIII-45 (Fig. 5).

The correlation between the single parameter $\mathrm{Chl} a$ content and tuber dry weight was slightly stronger than that between the MCA-variables of yield-relevant leaf pigment properties and tuber dry weight (Table 6, Fig. 6). The ranking was similar to that based on the MCA-variables of yield-relevant leaf pigment properties; however, the clones 13-VIII-49 and 13-VIII-60 exchanged their positions.

From Figs. 5 and 6, it can be deduced that the yield of cv. Taifun and clone 13-VIII49 was distinctly larger than could be expected from the regression line. Other additional parameters could have significantly affected tuber yield in addition to Chl $a$ and leaf pigment contents, respectively; for example, differences in the efficiencies of the light and dark reactions of photosynthesis, differences in assimilate partitioning resulting in the development of a larger photosynthetic area that later contributed more assimilates to tuber growth, or a higher sink strength of the developing tubers.

Testing the Chl fluorescence parameters for their applicability to yield predictions revealed that only the measure of the density of the reaction centres $\left(\mathrm{RC} / \mathrm{CS}_{\mathrm{m}}\right)$ and the electron flux reducing end electron acceptors at the PSI acceptor side per $\mathrm{RC}\left(\mathrm{RE}_{0} / \mathrm{RC}\right)$, were significantly correlated with tuber yield, the first acting as a stimulant, the second as a de-stimulant (Table 7). $\mathrm{RC} / \mathrm{CS}_{\mathrm{m}}$ can be related to $\mathrm{Chl} a$ content per leaf area, because the heart of the reaction centre of the photosynthetic system is a pair of Chl $a$ molecules (Dashek and Miglani 2017). This hypothesis was tested, indicating a significant correlation $(P=0.003)$ between $\mathrm{RC} / \mathrm{CS}_{\mathrm{m}}$ and $\mathrm{Chl} a$ content, if clone TG97-403 was excluded (Fig. 7). Including the latter clone resulted in an insignificant relationship $(P=0.087)$.

The negative correlation of $\mathrm{RE}_{0} / \mathrm{RC}$ with tuber dry weight is best explained by linking $\mathrm{RE}_{0} / \mathrm{RC}$ with the energy absorption per reaction centre (ABS/RC), the ratio of both being

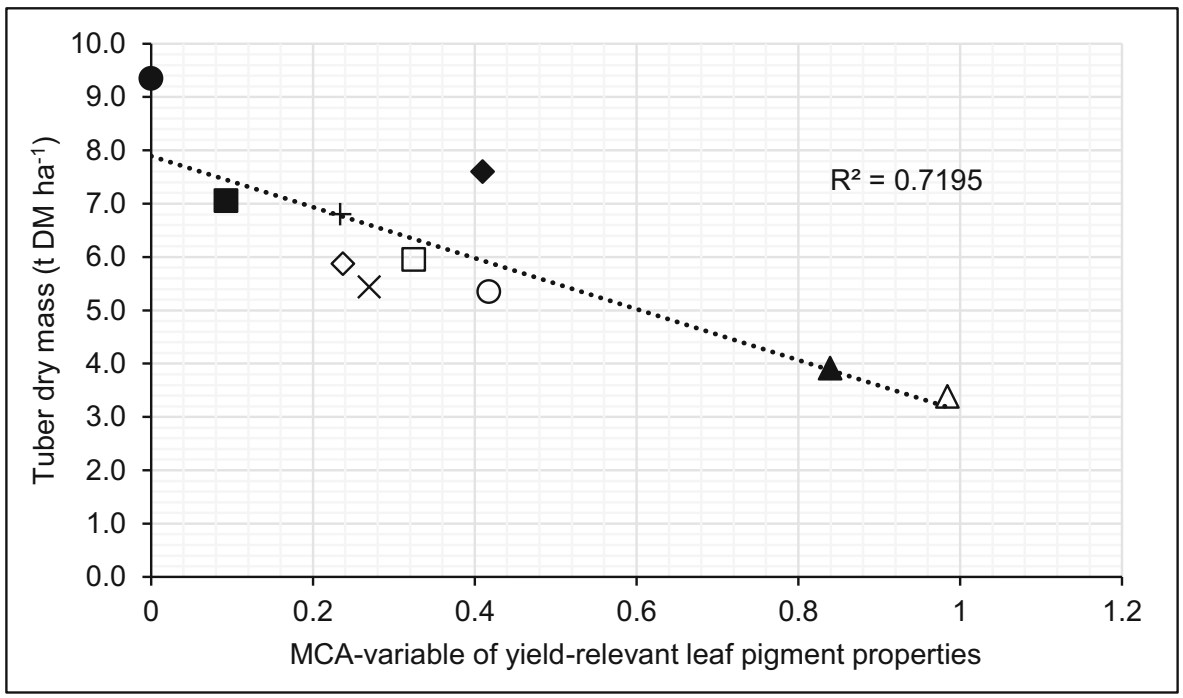

Fig. 5 Relationship between the MCA-variable of yield-relevant leaf pigment properties and tuber dry weight

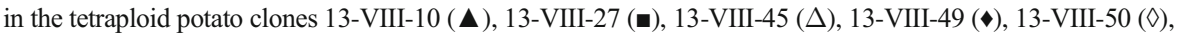
13-VIII-60 (०), TG-97-403 (+) and conventional cultivars Jelly (x), Satina ( $\square$ ) and Tajfun (•) 


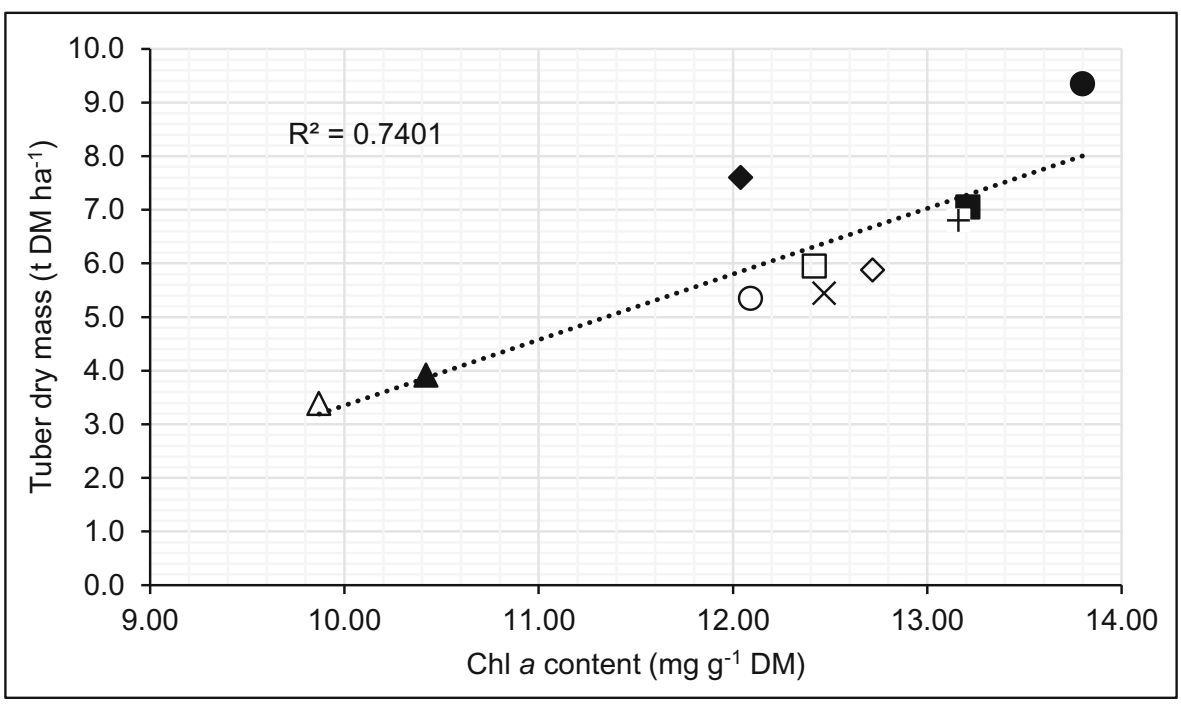

Fig. 6 Relationship between the Chl $a$ content of leaves and tuber dry weight in the tetraploid potato clones

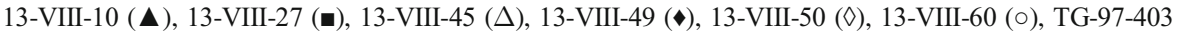
$(+)$ and conventional cultivars Jelly $(\mathrm{x})$, Satina $(\square)$ and Tajfun $(\bullet)$

$\varphi_{\mathrm{R} 0}(0.21 \pm 0.01$ for the cultivars and clones studied). The amount of energy absorbed depends on the balance between the light harvesting complexes and core complexes of the photosynthetic system. In the case of a larger ratio of light harvesting vs. core complexes, relatively more energy is absorbed by a single $\mathrm{RC}$, while a smaller ratio would result in less energy absorbed. In a light saturated environment typical of potato cultivation, a smaller ratio could be expected than for say plants growing on a forest floor. Thus, a

Table 7 Pearson correlation coefficient and probability level of the relationships of single Chl fluorescence parameters and tuber dry weight. Based on these results, the parameters were rated as 'stimulant' or 'de-stimulant' or not related (-)

\begin{tabular}{|c|c|c|c|}
\hline Parameter & $\begin{array}{l}\text { Pearson correlation } \\
\text { coefficient }\end{array}$ & Probability & Evaluation \\
\hline $\mathrm{RC} / \mathrm{CS}_{\mathrm{m}}$ & 0.647 & 0.043 & Stimulant \\
\hline $\mathrm{ABS} / \mathrm{RC}$ & -0.482 & 0.158 & - \\
\hline $\mathrm{TR}_{0} / \mathrm{RC}$ & -0.488 & 0.153 & - \\
\hline $\mathrm{DI}_{0} / \mathrm{RC}$ & -0.452 & 0.190 & - \\
\hline $\mathrm{ET}_{0} / \mathrm{RC}$ & -0.382 & 0.276 & - \\
\hline $\mathrm{RE}_{0} / \mathrm{RC}$ & -0.673 & 0.033 & De-stimulant \\
\hline $\mathrm{F}_{0}$ & 0.205 & 0.569 & - \\
\hline $\mathrm{F}_{\mathrm{m}}$ & 0.477 & 0.163 & - \\
\hline$\varphi_{\mathrm{P} 0}$ & 0.392 & 0.263 & - \\
\hline$\psi_{\mathrm{E} 0}$ & 0.135 & 0.711 & - \\
\hline$\varphi_{\mathrm{E} 0}$ & 0.176 & 0.628 & - \\
\hline$\delta_{\mathrm{R} 0}$ & -0.519 & 0.124 & - \\
\hline$\varphi_{\mathrm{R} 0}$ & -0.402 & 0.249 & - \\
\hline $\mathrm{PI}_{\mathrm{Abs}}$ & 0.306 & 0.390 & - \\
\hline $\mathrm{PI}_{\text {Total }}$ & -0.084 & 0.818 & - \\
\hline
\end{tabular}




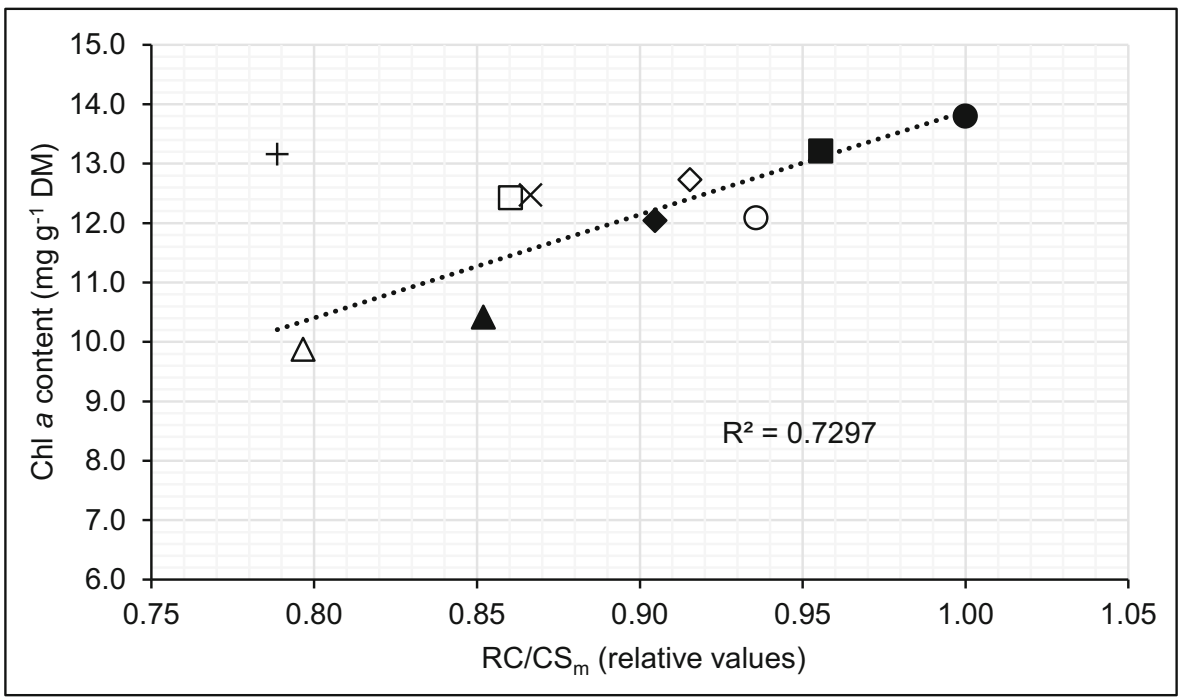

Fig. 7 Relationship between the measure of the density of the reaction centres $\left(\mathrm{RC} / \mathrm{CS}_{\mathrm{m}}\right)$ and leaf $\mathrm{Chl} a$ content in the tetraploid potato clones 13-VIII-10 ( $\mathbf{\Delta}), 13-\mathrm{VIII}-27(\boldsymbol{\bullet}), 13-\mathrm{VIII}-45(\Delta), 13-\mathrm{VIII}-49(\bullet), 13-$

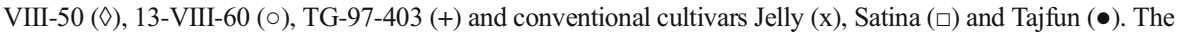
regression line was calculated without clone TG-97-403

smaller energy absorption per RC would represent a strategy to avoid the absorption of excessive energy per $\mathrm{RC}$ in a light exposed environment. Higher ratios of $\mathrm{RE}_{0} / \mathrm{RC}$ could, thus, be interpreted as indicative of an imbalance of energy absorption and transfer per RC. However, if this interpretation was correct, a negative correlation between ABS/RC and tuber dry weight should be expected, which was not confirmed (Table 7). Consequently, additional modulatory aspects must be involved, described by the efficiencies of electron transport $\left(\varphi_{\mathrm{P} 0}, \psi_{\mathrm{E} 0}, \varphi_{\mathrm{E} 0}, \delta_{\mathrm{R} 0}\right.$ and $\left.\varphi_{\mathrm{R} 0}\right)$.

From $\mathrm{RC} / \mathrm{CS}_{\mathrm{m}}$ and $\mathrm{RE}_{0} / \mathrm{RC}$, the MCA-variable of yield-relevant Chl fluorescence properties was calculated and found to be significantly correlated with tuber dry weight (probability $=0.021$ ). The ranking from best to worst $\mathrm{Chl}$ fluorescence properties of the studied clones and cultivars started with cv. Tajfun, followed by the clones 13-VIII-60, 13-VIII-50, 13-VIII-49, cv. Jelly, clone 13-VIII-27, cv. Satina, and the clones TG-97403, 13-VIII-10 and 13-VIII-45 (Fig. 8). This ranking differs from that established from the leaf pigment properties. However, cv. Taifun performed best and clones 13-VIII-10 and 13-VIII-45 worst in both approaches. As a consequence of this sophisticated result, in order to draw a general conclusion for the photosynthetic systems of the potato clones and cultivars studied, it was decided to combine both approaches.

The combination of yield-relevant leaf pigment and $\mathrm{Chl}$ fluorescence properties revealed that the tested clones and cultivars can be grouped into three distinct clusters (Fig. 9), with cv. Taifun performing best and clones 13-VIII-10 and 13-VIII-45 performing worst. The remaining clones and cultivars grouped in a distinct cluster, so that it is difficult to rank them according to their photosynthetic properties. Still, cv. Taifun and clone 13-VIII-49 plot distinctly above the regression line, indicating that tuber yield is positively affected by other parameters (for discussion see above). Remarkably, clone TG-97-403 plots above the regression line as well, which may be 


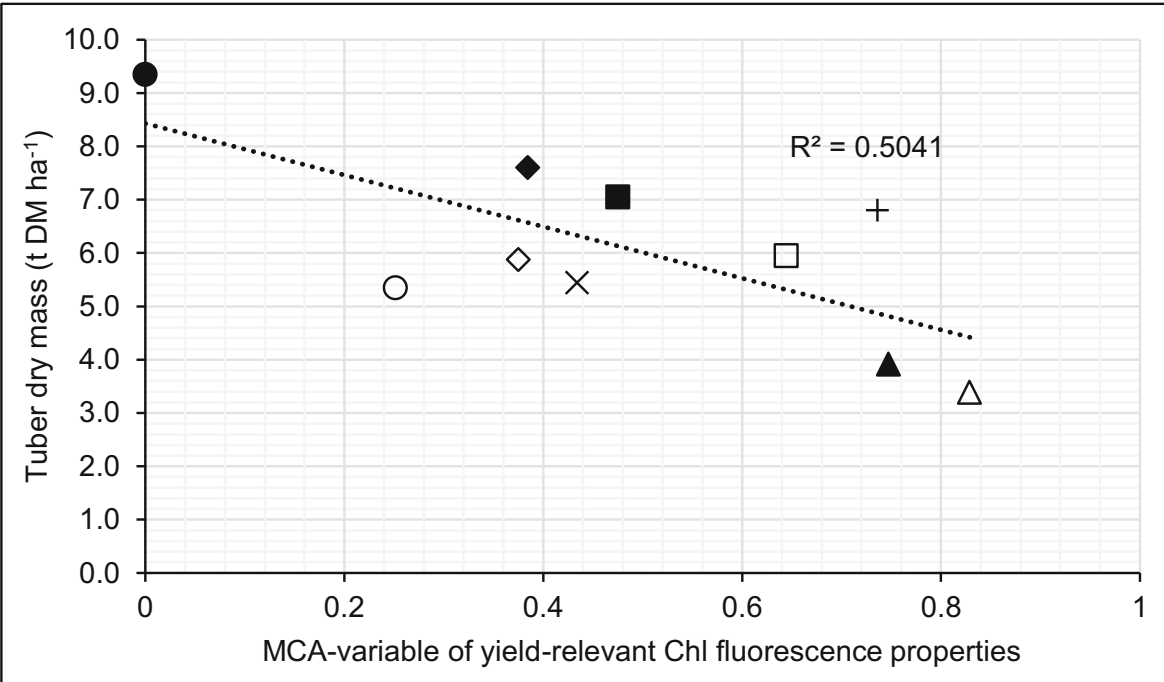

Fig. 8 Relationship between the MCA-variable of yield-relevant Chl fluorescence properties and tuber dry

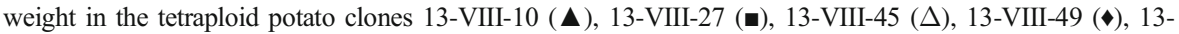
VIII-50 (৩), 13-VIII-60 (०), TG-97-403 (+) and conventional cultivars Jelly (x), Satina ( $\square)$ and Tajfun $(\bullet)$

due to the comparatively inefficient yield-relevant Chl fluorescence properties when compared to tuber dry weight (Fig. 8). With respect to clone TG-97-403, it is obvious that $\mathrm{Chl} a$ content and tuber dry weight are well correlated as in the other studied potato clones and cultivars (Fig. 6). However, the relationship between $\mathrm{RC} / \mathrm{CS}_{\mathrm{m}}$ and leaf Chl $a$ content was not typical for clone TG-97-403 (Fig. 7). This may be interpreted as an indication of a non-optimally adjusted $\mathrm{Chl}$ fluorescence in this clone, but an inaccurate measurement cannot be excluded.

In order to rank the tested potato clones and cultivars based on their efficiencies of the light reactions of $\mathrm{Chl}$ fluorescence, the generally applied parameters $\varphi_{\mathrm{P} 0}, \mathrm{PI}_{\mathrm{Abs}}$ and $\mathrm{PI}_{\text {Total }}$ for such kind of assessment (Strasser et al. 2000, 2004, 2010; Murchie and Lawson 2013) were used to calculate MCA-variables of Chl fluorescence efficiency. These allowed the tested clones and cultivars to be arranged into three groups (Fig. 10): cv. Tajfun and clone 13-VIII-60 performed most efficiently, followed by a medium rated group with the clones 13-VIII-10, 13-VIII-27, 13-VIII-49, 13-VIII-50, 13-VIII45 , and cv. Satina, finally clone TG-97-403 and cv. Jelly performing least efficiently. It should, however, be kept in mind that the efficiencies of Chl fluorescence of the studied clones and cultivars cannot be compared immediately, because they depend on both energy absorption per $\mathrm{RC}$ and ATP and $\mathrm{NADPH}+\mathrm{H}^{+}$consumption in the dark reactions of photosynthesis, which may differ among clones and cultivars.

A comparison of the MCA-variable of combined leaf pigment and Chl fluorescence yield-relevant properties and the MCA-variable Chl fluorescence efficiency revealed that in the low yielding clones 13-VIII-10 and 13-VIII-45 light reactions of photosynthesis were sufficiently efficient. Hence, yield of these clones could potentially be increased by promoting leaf $\mathrm{Chl}$ content and/or tuber induction in combination with sink strength of the developing tubers. By contrast, electron transport efficiency of the light reactions of photosynthesis was below average in clone TG-97-403 and cv. Jelly. 


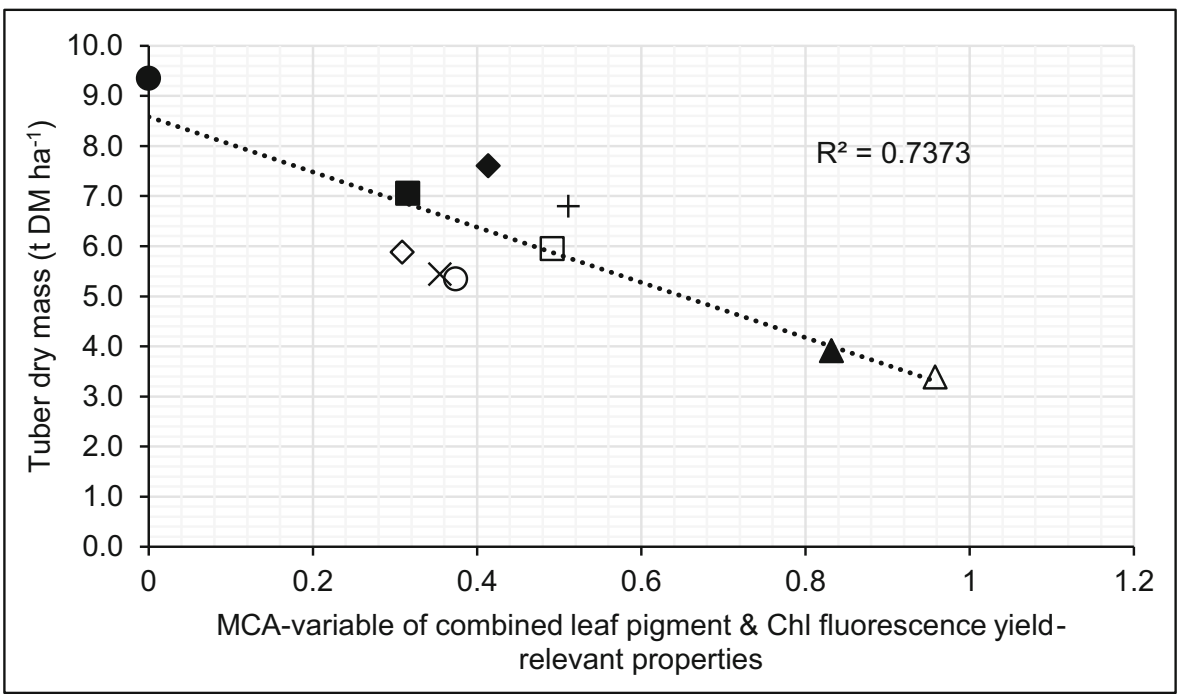

Fig. 9 Relationship between the MCA-variable of combined leaf pigment and Chl fluorescence yield-relevant properties and tuber dry weight in the tetraploid potato clones 13-VIII-10 ( $\mathbf{\Delta}), 13-\mathrm{VIII}-27(\mathbf{\square}), 13-\mathrm{VIII}-45(\Delta)$, 13-VIII-49 (४), 13-VIII-50 (৩), 13-VIII-60 (०), TG-97-403 (+) and conventional cultivars Jelly (x), Satina ( $\square$ ) and Tajfun $(\bullet)$

While for clone TG-97-403, this inefficiency has already been deduced from the MCAvariable of yield-relevant fluorescence properties (Fig. 9), the negative rating of cv. Jelly was unexpected. This latter result emphasises, in line with the correlation

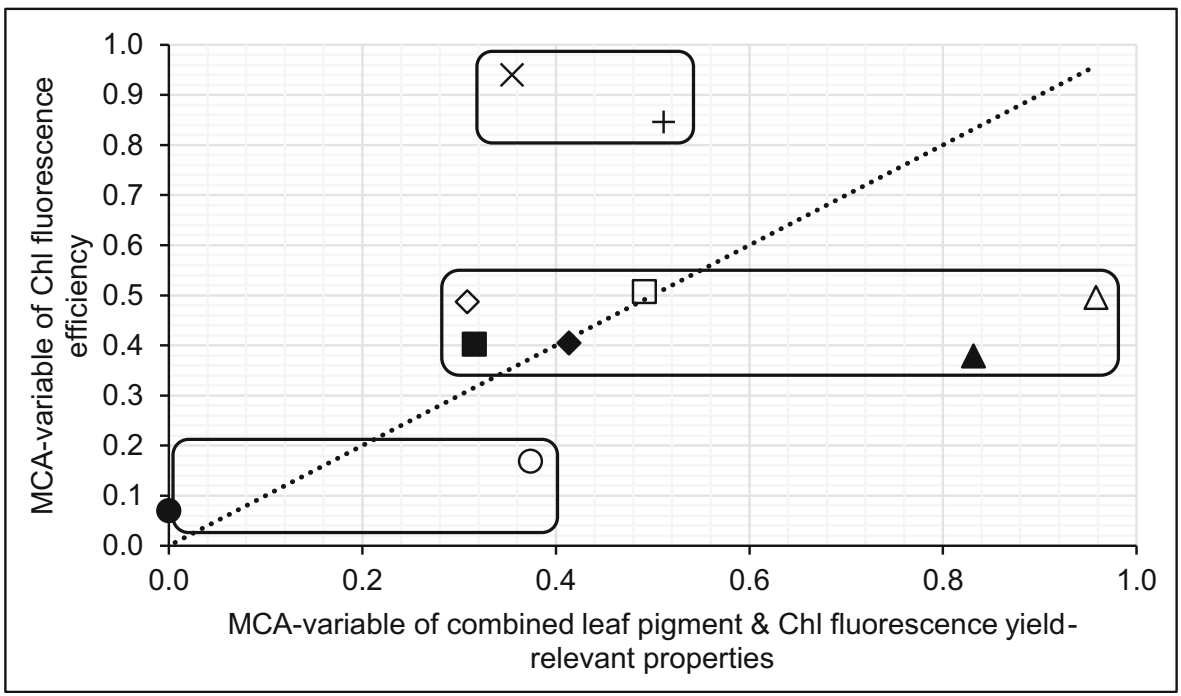

Fig. 10 Relationship between the MCA-variable of combined leaf pigment and Chl fluorescence yieldrelevant properties and the MCA-variable Chl fluorescence efficiency in the tetraploid potato clones 13-

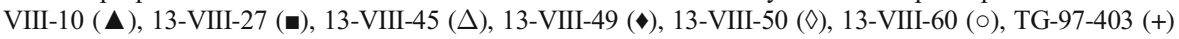
and conventional cultivars Jelly $(\mathrm{x})$, Satina $(\square)$ and Tajfun $(\bullet)$. The dotted line represents the positions where the data points would be situated if $\mathrm{Chl}$ fluorescence efficiency followed the MCA-variables of the yieldrelevant properties 
coefficients in Table 7, that less efficiently operating light reactions of photosynthesis do not necessarily impair potato tuber yield but describe an unbalanced relationship between light harvesting and dark reactions of photosynthesis. It may, however, increase the risk for the generation of reactive oxygen species and could, in the worst case, reduce the lifespan of leaves, although this development is non-compulsive.

\section{Conclusion}

The present study characterised seven new tetraploid potato clones of the IHAR-PIB in comparison with three established cultivars with respect to their photosynthetic capacities, as determined by leaf pigment content and Chl fluorescence parameters as well as tuber yield under integrated and organic fertilisation at four different locations. Based on the yield-relevant aspects of the present results, the clones 13-VIII-10 and 13-VIII-45 cannot be recommended. The commercially available cv. Taifun behaved best with respect to yield and photosynthetic properties. This Polish cultivar is recommended as one of the best for cultivation in climate change areas, as it is resistant to heat and drought. In addition, plants remove moisture from the deeper layers of the soil but limit foliar transpiration. Last but not least, a change of drought and rain does not cause cracking, hollowing and germination of tubers (pers. communications). Altogether, these characteristics of cv. Taifun may have contributed to the highest tuber yield and photosynthetic capacity observed among the studied clones and cultivars. The remaining clones and cultivars do not differ distinctly from each other in yield and yield-relevant photosynthetic properties. For clone TG-97-403 and cv. Jelly this rating should be considered with care, because the Chl fluorescence measurements suggest that the light reactions of photosynthesis may not be as harmonised or efficient as in the other potato clones and cultivars.

The four localities, where the potato clones and cultivars were cultivated, affected yield and photosynthetic properties in different ways. An unambiguous effect on tuber yield could not be detected, but yield was rather low at Chwałowice when compared with the other localities. Chlorophyll and carotenoid contents of leaves were affected by the production system and were generally lower under organic fertilisation. By contrast, most of the chlorophyll fluorescence characteristics followed soil nitrogen content, while $\mathrm{F}_{\mathrm{m}}$ followed the production system, as could be expected due to the, albeit weak, relationship between $\mathrm{F}_{\mathrm{m}}$ and $\mathrm{Chl}$ content reported in literature. Precipitation affected the ratio Car/total Chl, especially within a production system, which suggests that temporary water shortage in combination with excessive light energy could have led to the enhanced production of reactive oxygen species inducing carotenoid synthesis.

Acknowledgements Open access funding provided by University of Natural Resources and Life Sciences Vienna (BOKU).

Funding Information The project was financed by the resources of National Science Centre of Poland grant based on a decision number DEC-2013/11/B/NZ9/00778.

\section{Compliance with Ethical Standards}

Conflict of Interest The authors declare that they have no conflicts of interest. 
Open Access This article is distributed under the terms of the Creative Commons Attribution 4.0 International License (http://creativecommons.org/licenses/by/4.0/), which permits unrestricted use, distribution, and reproduction in any medium, provided you give appropriate credit to the original author(s) and the source, provide a link to the Creative Commons license, and indicate if changes were made.

\section{References}

Ashraf M, Harris PJC (2013) Photosynthesis under stressful environments: an overview. Photosynthetica 51(2):163-190

Brestic M, Zivcak M, Kalaji HM, Carpentier R, Allakhverdiev SI (2012) Photosystem II thermostability in situ: environmentally induced acclimation and genotype-specific reactions in Triticum aestivum L. Plant Physiol Bioch 57:93-105

Chrzanowska M (2017) Multidimensional comparative analysis of the Polish agri-food sector in regard to other EU countries in the years 2004-2014. Proceedings of the 2017 International Conference "Economic science for rural development" No 44 Jelgava, LLU ESAF, 27-28 April 2017, pp. 323-329

Dashek WV, Miglani GS (2017) Plant cells and their organelles. ISBN: 978-0-470-97686-9, Wiley-Blackwell: 432 p

Davison PA, Hunter CN, Horton P (2002) Overexpression of $\beta$-carotene hydroxylase enhances stress tolerance in Arabidopsis. Nature 418:203-206

Demmig-Adams B, Adams WW III (1996) The role of xanthophyll cycle carotenoids in the protection of photosynthesis. Trends Plant Sci 1:21-26

Govindjee (2004) Chlorophyll $a$ fluorescence: a bit of basics and history. In: Papageorgiou GC, Govindjee (eds) Chlorophyll $a$ fluorescence: a signature of photosynthesis. Advances in photosynthesis and respiration. Springer, Dordrecht, pp 1-42

Grabiński T, Wydymus S, Zeliaś A. (1989) Metody taksonomii numerycznej w modelowaniu zjawisk społeczno-gospodarczych, PWN, Warszawa, Wyd. I, pp 84-96

Ierna A, Parisi B (2014) Crop growth and tuber yield of "early" potato crop under organic and conventional farming. Sci Hortic 165:260-265

Kalaji HM, Govindjee BK, Kościelniak J, Żuk-Gołaszewska K (2011a) Effects of salt stress on photosystem II efficiency and $\mathrm{CO}_{2}$ assimilation of two Syrian barley landraces. Environ Exp Bot 73:64-72

Kalaji HM, Bosa K, Kościelniak J, Hossain Z (2011b) Chlorophyll $a$ fluorescence - a useful tool for the early detection of temperature stress in spring barley (Hordeum vulgare L.). OMICS 15(12):925-934

Kalaji MH, Carpentier R, Allakhverdiev SI, Bosa K (2012) Fluorescence parameters as early indicators of light stress in barley. J Photoch Photobio B 112:1-6

Kalaji HM, Jajoo A, Oukarroum A, Brestic M, Zivcak M, Samborska IA, Cetner MD, Łukasik I, Goltsev V, Ladle RJ (2016) Chlorophyll $a$ fluorescence as a tool to monitor physiological status of plants under abiotic stress conditions. Acta Physiol Plant 38:1-11

Kitajima K, Hogan KP (2003) Increases of chlorophyll a/b ratios during acclimation of tropical woody seedlings to nitrogen limitation and high light. Plant Cell Environ 26:857-865

Maggio A, Carillo P, Bulmetti GS, Fuggi A, Barbieri G, De Pascale S (2008) Potato yield and metabolic profiling under conventional and organic farming. Eur J Agron 28(3):343-350

Mauromicale G, Ierna A, Marchese M (2006) Chlorophyll fluorescence and chlorophyll content in fieldgrown potato as affected by nitrogen supply, genotype, and plant age. Photosynthetica 44(1):76-82

Mierowska AJ (1996) Intensywność wzrostu młodych drzew jabłoni i gruszy w zależności od odmiany i typu podkładki. Akademia Rolnicza w Szczecinie, Szczecin, pp 1-81

Miranda V, Baker NR, Long SP (1981) Limitations of photosynthesis in different regions of the Zea mays leaf. New Phytol 89:179-190

Murchie EH, Lawson T (2013) Chlorophyll fluorescence analysis: a guide to good practice and understanding some new applications. J Exp Bot 64:3983-3998. https://doi.org/10.1093/jxb/ert208

Netto AT, Campostrini E, de Oliveira GJ, Bressan-Smith RE (2005) Photosynthetic pigments, nitrogen, chlorophyll $a$ fluorescence and SPAD-502 readings in coffee leaves. Sci Hortic 104:199-209

Reddivari L, Hale AL, Miller JC (2007) Genotype, location, and year influence antioxidant activity, carotenoid content, phenolic content, and composition in specialty potatoes. J Agric Food Chem 55(20):8073-8079

Strasser RJ, Srivastava A, Tsimilli-Michael M (2000) The fluorescence transient as a tool to characterize and screen photosynthetic samples. In: Yunus M, Pathre U, Mohanty P (eds) Probing photosynthesis: mechanism, regulation and adaptation. Taylor and Francis, London, pp 443-480 
Strasser RJ, Tsimilli-Michael M, Srivastava A (2004) Analysis of the chlorophyll $a$ fluorescence transient. In: Papageorgiou GC, Govindjee (eds) Chlorophyll $a$ fluorescence: a signature of photosynthesis. Advances in Photosynthesis and Respiration. Springer, Dordrecht, pp 321-362

Strasser RJ, Tsimilli-Michael M, Qiang S, Goltsev V (2010) Simultaneous in vivo recording of prompt and delayed fluorescence and 820-nm reflection changes during drying and after rehydration of the resurrection plant Haberlea rhodopensis. Biochim Biophys Acta-Bioenerg 1797(6-7):1313-1326

Trawczyński C (2015) Bilans azotu, fosforu i potasu drugiej rotacji płodozmianu w systemie produkcji ekologicznej na glebie lekkiej. Fragm Agron 32(2):87-96

Veres S, Malik AI, Rengel Z (2017) Differential nitrogen supply causes large variability in photosynthetic traits in wheat germplasm. Crop Pasture Sci 68:703-712. https://doi.org/10.1071/CP17126

Von Hack H, Gall H, Klemke T, Klose R, Meier U, Stauß R, Witzenberger A (1993) Phänologische Entwicklungsstadien der Kartoffel (Solanum tuberosum L.). Phenological growth stages of potato (Solanum tuberosum L.). Codierung und Beschreibung nach der erweiterten BBCH-Skala mit Abbildungen. Nachrichtenblatt des Deutschen Pflanzenschutzdienstes 45(1):11-19

Vos J, Bom M (1993) Hand-held chlorophyll meter: a promising tool to assess the nitrogen status of potato foliage. Potato Res 36(4):301-308

Wellburn AR (1994) The spectral determination of chlorophylls $a$ and $b$, as well as total carotenoids, using various solvents with spectrophotometers of different resolution. J Plant Physiol 144(3):307-313

Zivcak M, Kalaji HM, Shao HB, Olsovska K, Brestic M (2014) Photosynthetic proton and electron transport in wheat leaves under prolonged moderate drought stress. J Photochem Photobiol B-Biol 137:107-115

Publisher's Note Springer Nature remains neutral with regard to jurisdictional claims in published maps and institutional affiliations.

\title{
Affiliations
}

\section{Anna J. Keutgen ${ }^{1,2} \cdot$ Norbert Keutgen ${ }^{1,3}$ • Elżbieta Wszelaczyńska ${ }^{2}$ • Jarosław Pobereżny $^{2} \cdot$ Dorota Milczarek $^{4} \cdot$ Beata Tatarowska $^{4} \cdot$ Bogdan Flis $^{4}$}

\author{
Norbert Keutgen \\ norbert.keutgen@boku.ac.at \\ Elżbieta Wszelaczyńska \\ wszela@utp.edu.pl \\ Jarosław Pobereżny \\ poberezny@utp.edu.pl \\ Dorota Milczarek \\ d.milczarek@ihar.edu.pl \\ Beata Tatarowska \\ b.tatarowska@ihar.edu.pl \\ Bogdan Flis \\ b.flis@ihar.edu.pl
}

1 Division of Vegetables and Ornamentals at the Department of Crop Sciences, BOKU-University of Natural Resources and Life Sciences, Gregor Mendel Str. 33, 1180 Vienna, Austria

2 Department of Microbiology and Food Technology, UTP University of Science and Technology, ul. ks. A. Kordeckiego 20A, 85-225 Bydgoszcz, Poland

3 Department of Genetics, Physiology, and Plant Biotechnology, UTP University of Science and Technology, Bernardyńska 6, 85-029 Bydgoszcz, Poland

4 Plant Breeding and Acclimatization Institute (IHAR) - National Research Institute, Młochów Research Center, Platanowa 19, 05-831 Młochów, Poland 